\title{
ANALISIS INKLUSI KEUANGAN DAN PEMERATAAN PENDAPATAN DI INDONESIA
}

\author{
Bintan Badriatul Ummah $^{1}$, Nunung Nuryartono ${ }^{2}$, Lukytawati Anggraeni ${ }^{2}$ \\ ${ }^{1}$ Mahasiswa Magister Program Studi Ilmu Ekonomi, FEM IPB \\ ${ }^{2}$ Staf Pengajar FEM IPB
}

Artikel diterima Desember 2014

Artikel disetujui untuk dipublikasikan Juli 2015

\begin{abstract}
Recent study showed that increasing access and usage of banking services reduce income inequality. Nowdays banking access in Indonesia is increasing but income equality gap is widening. Therefore, by using secondary data from 33 provinces 20072011, this paper aims to measure the level of access and usage for financial services across provinces in Indonesia by Index of Financial Inclusion, analyze the factors that affect financial inclusion by panel tobit regression, and describe the relationship between financial inclusion and income distribution in Indonesia. The results show that the level of financial inclusion in Indonesia is classified as low. The size of the economy and income inequality positively affect the level of financial inclusion. Opposite the research hypothesis, widening income inequality lead to higher financial inclusion in Indonesia. Moreover, the number of mobile phone and the internet user affect positively the level of financial inclusion in Indonesia. Income inequality and financial inclusion has a one-way relationship, income inequality affects financial inclusion in Indonesia but does not vice versa.
\end{abstract}

Keywords : Financial Inclusion, income inequality

\section{PENDAHULUAN}

\section{Latar Belakang}

Sektor perbankan merupakan salah satu sektor yang menguasai industri keuangan Indonesia. Perbankan memiliki aset terbesar dibandingkan dengan lembaga keuangan yang ada di industri keuangan Indonesia yaitu mencapai $\mathrm{Rp} 4.330$ triliun atau 78 persen dari total aset industri keuangan pada tahun 2012. Besarnya aset perbankan menunjukkan perbankan merupakan lembaga keuangan yang mampu menarik konsumen lebih banyak dibandingkan dengan lembaga keuangan lainnya. Masyarakat lebih memilih menyimpan asetnya di perbankan dalam bentuk dana pihak ketiga.

Saat ini sektor perbankan di Indonesia mengalami perkembangan yang positif, hal ini dapat dilihat dari kontribusi perbankan terhadap PDB Indonesia yang setiap tahunnya terus meningkat. Kontribusi sektor perbankan terhadap PDB Indonesia tahun 2013 mencapai Rp113 triliun, sedangkan pada tahun 2007 hanya mencapai Rp78 triliun (BPS 2014). Perkembangan perbankan juga dapat dilihat dari jumlah infrastruktur fisik yang terus mengalami peningkatan. Salah satu infrastruktur fisik dari perbankan adalah kantor cabang yang didirikan di daerah-daerah yang tersebar di seluruh wilayah Indonesia. Dalam laporan pengawasan 
perbankan BI tahun 2012, tercatat hampir 2000 penambahan unit kantor baru Bank Umum Konvensional (BUK) selama periode 2012 yang meliputi kantor cabang, kantor cabang pembantu, dan kantor kas. Adanya penambahan kantor cabang perbankan ini meningkatkan jumlah kantor cabang BUK yang tersebar di seluruh Indonesia sebesar 20\% dari 9110 kantor pada tahun 2010 menjadi 18.303 kantor pada tahun 2013 (SPI 2013).

Tabel 1 Jumlah Total Aset Industri Keuangan Indonesia Tahun 2012

\begin{tabular}{|c|c|c|}
\hline $\begin{array}{c}\text { Lembaga Jasa } \\
\text { Keuangan }\end{array}$ & $\begin{array}{c}\text { Aset } \\
\text { (Triliun Rp) }\end{array}$ & $\%$ \\
\hline Bank & $4.330,0$ & 78,9 \\
\hline Asuransi & 569,3 & 10,4 \\
\hline Dana Pensiun & 158,4 & 2,9 \\
\hline Lembaga & 356,1 & 6,5 \\
\hline Pembiayaan & & \\
\hline $\begin{array}{l}\text { Lembaga Jasa } \\
\text { Keuangan } \\
\text { Lainnya* }\end{array}$ & 75,8 & 1,4 \\
\hline Total & $5.489,6$ & 100,0 \\
\hline \begin{tabular}{l}
\multicolumn{1}{c}{ Tanpa } \\
Infrastruktur, I \\
Jaminan Sosial, \\
Mikro
\end{tabular} & $\begin{array}{l}\text { Lembaga } P \\
\text { embaga Penye } \\
\text { dan Lembaga } \mathrm{K}\end{array}$ & $\begin{array}{l}\text { aminan } \\
\text { enggara } \\
\text { uangan }\end{array}$ \\
\hline
\end{tabular}

Sumber : OJK 2014 (diolah)

Seiring dengan peningkatan jumlah kantor cabang, jumlah tabungan, yang dapat dilihat dari jumlah Dana Pihak Ketiga (DPK), serta kredit yang disalurkan melalui perbankan juga mengalami peningkatan. Jumlah DPK yang dihimpun BUK meningkat sebesar 57\% dari tahun 2006 sampai 2013 yaitu menjadi 3,66 triliun rupiah (BI 2013). Sedangkan jumlah kredit yang disalurkan oleh BUK meningkat sebesar 88\% dari tahun 2010 sampai tahun 2013 yaitu mencapai 3,3 triliun rupiah.

Demirguc-Kunt et al. (2008) menyatakan bahwa sektor keuangan merupakan inti dari proses pembangunan. Levine (1997) meneliti berdasarkan analisis empiris baik pada tingkat perusahaan, industri, rumah tangga, maupun perbandingan antar negara, bahwa terdapat hubungan positif antara fungsi sistem keuangan dengan pertumbuhan ekonomi dalam jangka panjang. Pembangunan sektor keuangan, terutama sektor perbankan, dapat mendorong pertumbuhan ekonomi (Cheng dan Degryse 2006). Pembangunan sektor keuangan, terutama sektor perbankan, dapat meningkatkan akses dan penggunaan jasa perbankan oleh masyarakat. Semakin terbukanya akses terhadap jasa keuangan, masyarakat diharapkan dapat memanfaatkan akses tersebut serta meningkatkan pendapatannya melalui penyaluran kredit oleh lembaga keuangan terutama apabila digunakan untuk kegiatan produktif. Sulitnya akses terhadap jasa keuangan menyebabkan masyarakat miskin harus mengandalkan tabungan yang terbatas untuk investasi dan pengusaha kecil harus mengandalkan laba untuk meneruskan usaha. Akibatnya, ketimpangan pendapatan tidak berkurang dan pertumbuhan ekonomi melambat (Allen et al. 2012).

Sektor perbankan juga menjadi salah satu sektor yang memberikan kontribusi terhadap pendapatan nasional dan dapat menciptakan pertumbuhan ekonomi. Bank merupakan lembaga perantara keuangan yang dapat menghubungkan pihak yang memiliki modal dengan pihak yang membutuhkan modal. Fungsi bank sebagai lembaga perantara keuangan dapat mengurangi biaya transaksi, pembagian risiko, dan informasi asimetris (Miskhin 2008). Perantara keuangan memiliki peranan penting dalam meningkatkan efisiensi ekonomi karena membantu pasar keuangan 
menyalurkan dana kepada pihak yang mempunyai peluang investasi yang produktif.

Seiring dengan berkembangnya sektor perbankan, distribusi layanan jasa perbankan juga harus merata. Meskipun jumlah kantor cabang bank, DPK yang terhimpun, serta kredit yang disalurkan semakin meningkat, namun masih terdapat masyarakat Indonesia yang belum dapat mengakses jasa perbankan. Berdasarkan data Global Financial Index World Bank tahun 2011, jumlah penduduk dewasa di Indonesia baik yang memiliki rekening, menabung, atau meminjam di lembaga keuangan formal, salah satunya sektor perbankan, pada tahun 2011 masih di bawah 20\%. Jasa keuangan formal sulit diakses terutama oleh penduduk desa sehingga mereka memilih untuk meminjam dan menabung di lembaga keuangan informal (Anggraeni 2009). Rendahnya akses ini disebabkan karena tingkat pendapatan yang rendah, tata operasional bank rumit, kurangnya edukasi keuangan dan perbankan, biaya administrasi bank yang tinggi serta jauhnya lokasi bank dari tempat tinggal mereka.

Salah satu cara untuk mengetahui distribusi layanan sektor perbankan dapat diukur dengan tingkat inklusi keuangan. Inklusi keuangan berkaitan dengan kemudahan dalam mengakses dan menggunakan jasa keuangan (Sarma 2012; Demirguc-Kunt dan Klapper 2012; Gerdeva dan Rhyne 2011; BI 2012). Saat ini, inklusi keuangan telah menjadi agenda penting di berbagai negara termasuk Indonesia. Pada bulan Juni 2012, Bank Indonesia bekerjasama dengan Sekretariat Wakil Presiden - Tim Nasional Percepatan Penanggulangan Kemiskinan (TNP2K) dan Badan Kebijakan Fiskal Kementerian Keuangan mengeluarkan Strategi Nasional Keuangan Inklusif.
Program ini dibentuk untuk mendukung pemerintah dalam mengurangi angka kemiskinan dan pembangunan ekonomi yang inklusif dan berkelanjutan. Dalam Strategi Nasional Keuangan Inklusif, strategi keuangan inklusif dijabarkan dalam 6 pilar yaitu edukasi keuangan, fasilitas keuangan publik, pemetaan informasi keuangan, kebijakan/ peraturan pendukung, fasilitas intermediasi dan distribusi, serta perlindungan konsumen.

Salah satu tujuan dari strategi tersebut adalah menjadikan strategi keuangan inklusif sebagai bagian dari strategi besar pembangunan ekonomi, penanggulangan kemiskinan, pemerataan pendapatan dan stabilitas sistem keuangan. Keuangan yang semakin inklusif dapat memberikan akses terhadap jasa keuangan yang lebih luas bagi setiap penduduk, terutama bagi kelompok miskin dan marjinal yang memiliki keterbatasan akses terhadap layanan keuangan. Masyarakat miskin memiliki kesempatan untuk memperbaiki kondisi hidupnya menjadi lebih sejahtera dengan mengakses layanan keuangan. Hal ini dapat mendorong pendapatan masyarakat miskin semakin meningkat sehingga kesenjangan pendapatan dapat berkurang.

Beberapa hasil penelitian telah menunjukkan bahwa pembangunan di sektor keuangan dapat mengurangi ketimpangan pendapatan (Beck et al. 2007; Shahbaz dan Islam 2011; Ang 2010) dan mengurangi kemiskinan (Jalilian dan Kirkpatrick 2002). Pembangunan sektor keuangan dapat mendorong pertumbuhan ekonomi melalui dua jalur (Tiwari et al. 2013). Pertama, kredit yang lebih murah membuat investasi semakin menarik, dimana pengusaha kecil memiliki peluang untuk mendapatkan keuntungan lebih besar. Kemudahan akses terhadap 
modal bagi pengusaha dapat memperluas kesempatan kerja, meningkatkan output, dan meningkatkan kesejahteraan masyarakat miskin. Jalur kedua, meminjam dengan biaya rendah memberi keuantungan bagi masyarakat miskin untuk investasi pendidikan dan kesehatan. Investasi dalam pendidikan dan kesehatan dapat meningkatkan kualitas sumber daya manusia yang merupakan jalan keluar dari perangkap kemiskinan. Adanya perbaikan dalam kesejahteraan masyarakat miskin melalui akses jasa keuangan dapat mengurangi ketimpangan pendapatan yang terjadi.

Pembangunan di sektor perbankan dapat mengurangi hambatan terhadap akses perbankan sehingga akses terhadap perbankan lebih mudah terutama bagi masyarakat miskin yang belum secara maksimal menggunakan atau memanfaatkan layanan keuangan yang disediakan oleh lembaga keuangan formal di Indonesia (Sanjaya 2014). Kemudahan akses ini dapat berupa rendahnya biaya transaksi, jarak yang semakin dekat dengan bank, atau rendahnya agunan yang ditetapkan oleh bank. Akses perbankan yang mudah bagi kelompok masyarakat miskin ini dapat meningkatkan efisiensi alokasi modal, yang dapat mempercepat pertumbuhan agregat, dan mengurangi hambatan dalam akses kredit produktif, yang dapat meningkatkan kesejahteraan hidup masyarakat miskin sehingga dapat keluar dari perangkap kemiskinan. Peningkatan kesejahteraan masyarakat miskin ini secara tidak langsung dapat mengurangi ketimpangan pendapatan. Tetapi di Indonesia menunjukkan hal yang sebaliknya, akses dan penggunaan jasa perbankan meningkat, begitu juga dengan ketimpangan pendapatan semakin besar.
Berdasarkan SPI BI 2013, proporsi jumlah DPK yang dihimpun BUK terhadap PDB dan proporsi kredit yang disalurkan BUK terhadap PDB dari tahun ke tahun mengalami peningkatan. Begitu pula pertumbuhan ekonomi yang terjadi di Indonesia terus meningkat di mana pada tahun 2012 mencapai 6,23 persen. Namun, pertumbuhan tersebut tidak diikuti oleh semakin membaiknya pemerataan pendapatan. Kondisi ini dapat dilihat dari koefisien gini Indonesia yang semakin besar, yaitu 0,33 pada tahun 2002 menjadi 0,41 pada tahun 2013 (BPS 2014).

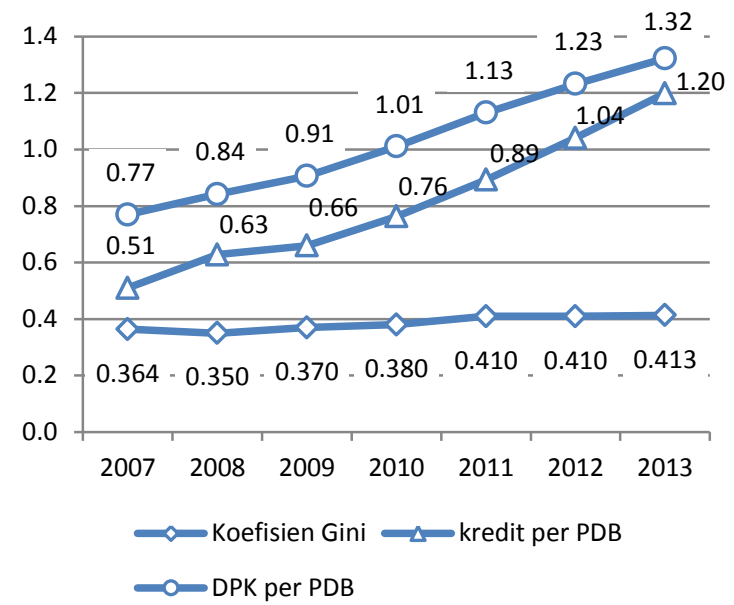

Gambar 1 Pertumbuhan Rasio Kredit per PDB, Rasio DPK per PDB dan Koefisien Gini di Indonesia tahun 2007-2013

Sumber: BPS 2014, SPI BI 2014 (diolah)

Gambar 1 menunjukkan bahwa di Indonesia terjadi peningkatan dalam penggunaan jasa perbankan tetapi ketimpangan pendapatan semakin besar. Hal ini menimbulkan pertanyaan terkait keterkaitan inklusivitas perbankan di Indonesia dengan pemerataan pendapatan. Oleh karena itu perlu dianalisis lebih lanjut terkait kondisi tersebut di Indonesia. 
Tujuan penelitian ini adalah untuk mengetahui hubungan inklusi keuangan dengan ketimpangan pendapatan di Indonesia serta menganalisis tingkat inklusi keuangan setiap provinsi di Indonesia serta faktor-faktor yang mempengaruhinya.

\section{TINJAUAN PUSTAKA}

\section{Konsep Inklusi Keuangan}

Konsep inklusi keuangan muncul setelah adanya konsep eksklusi keuangan. Leyshon dan Thrift (1995) mendefinisikan eksklusi keuangan sebagai sebuah proses yang mencegah kelompok sosial dan individu dari memperoleh akses terhadap sistem keuangan formal. European Commision (2008) menjelaskan bahwa eksklusi keuangan merupakan sebuah proses dimana orang menghadapi kesulitan dalam mengakses dan/atau menggunakan jasa keuangan dan produk di pasar pada umumnya yang sesuai dengan kebutuhan mereka sehingga mereka tidak dapat menjalani kehidupan sosial dalam masyarakat di tempat mereka berada. Berbagai peneliti mendefinisikan inklusi keuangan sebagai kebalikan dari eksklusi keuangan.

Sarma (2012) mendefinisikan inklusi keuangan sebagai sebuah proses yang menjamin kemudahan dalam akses, ketersediaan, dan manfaat dari sistem keuangan formal bagi seluruh pelaku ekonomi. Tidak jauh berbeda dengan definisi Sarma, Gerdeva dan Rhyne (2011) mendefinisikan inklusi keuangan sebagai sebuah kondisi dimana semua orang dapat mengakses jasa keuangan berkualitas, tersedia dengan harga terjangkau, dengan cara yang nyaman dan memuaskan. Sedangkan Demirguc-Kunt dan Klapper (2012) mendefinisikan inklusi keuangan sebagai penyediaan akses jasa keuangan yang luas tanpa hambatan harga maupun non harga dalam penggunaannya.

Bank Indonesia (2014)

mendefinisikan keuangan inklusif (financial inclusion) sebagai seluruh upaya yang bertujuan meniadakan segala bentuk hambatan yang bersifat harga maupun non harga, terhadap akses masyarakat dalam memanfaatkan layanan jasa keuangan. Indikator yang dapat dijadikan ukuran dari keuangan yang inklusif sebuah negara adalah ketersediaan / akses untuk mengukur kemampuan penggunaan jasa keuangan formal dalam hal keterjangkauan fisik dan harga, penggunaan untuk mengukur kemampuan penggunaan aktual produk dan jasa keuangan (antara lain keteraturan, frekuensi dan lama penggunaan), kualitas untuk mengukur apakah atribut produk dan jasa keuangan telah memenuhi kebutan pelanggan, dan kesejahteraan untuk mengukur dampak layanan keuangan terhadap tingkat kehidupan pengguna jasa.

Beck et al. (2006) menyatakan bahwa konsep akses jasa keuangan dengan penggunaan jasa keuangan adalah konsep yang berbeda. Pelaku ekonomi mungkin memiliki akses terhadap jasa keuangan tetapi tidak ingin menggunakannya. Hal ini dapat dikarenakan alasan sosial budaya ataupun biaya imbangan yang terlalu tinggi untuk menggunakan jasa keuangan. Oleh karena itu, Beck et al. membedakan kedua konsep terkait jangkauan sektor keuangan, yaitu (i) adanya akses dan kemungkinan dalam menggunakan jasa keuangan, dan (ii) penggunaan jasa keuangan aktual artinya yang benar-benar menggunakan jasa keuangan. Adanya akses dan kemungkinan dalam menggunakan jasa keuangan di suatu daerah diukur dengan 
jumlah kantor cabang perbankan dan ATM yang ada di daerah tersebut. Semakin tinggi intensitas kantor cabang bank dan ATM maka semakin tinggi pula kemungkinan dalam mengakses dan kesempatan dalam menggunakan jasa keuangan. Sedangkan konsep kedua diukur dengan jumlah rekening kredit dan deposit serta rata-rata kredit dan deposit per GDP per kapita. Tingginya kepemilikan rekening kredit dan deposit menunjukkan tingginya penggunaan jasa keuangan.

Demirguc-Kunt A et al. (2008) menjelaskan secara rinci terkait perbedaan akses terhadap jasa keuangan dengan penggunaan jasa keuangan. Akses pada dasarnya ditujukan untuk penawaran sedangkan penggunaan jasa keuangan ditentukan baik oleh penawaran maupun permintaan. Meskipun seseorang berpendapatan tinggi memiliki akses terhadap jasa keuangan, ia mungkin saja tidak tertarik untuk menggunakan jasa tersebut. Begitu pula dengan nasabah, baik individu maupun perusahaan, belum tentu mau meminjam uang meskipun ditawari dengan suku bunga yang rendah.

World Bank (2009) menjelaskan bahwa di dalam dunia yang sempurna akses terhadap jasa keuangan dapat diukur dari jumlah individu, rumah tangga, maupun perusahaan yang menyimpan, menerima kredit, melakukan pembayaran, dan menggunakan produk keuangan lainnya dari berbagai lembaga keuangan baik yang formal maupun yang informal. Indikator yang paling baik untuk mengukur akses jasa keuangan adalah jumlah orang yang menggunakan jasa simpanan dan jumlah orang yang menggunakan jasa pinjaman di lembaga keuangan. Namun, tidak semua negara yang memiliki data tersebut secara lengkap, terutama dari lembaga keuangan mikro dan lembaga keuangan informal. Untuk mengukur akses terhadap penggunaan jasa simpanan, indikator yang paling tepat digunakan adalah jumlah rekening deposit per 1000 orang dewasa.

Beberapa penelitian telah membedakan antara konsep akses jasa keuangan dengan penggunaan jasa keuangan. Akses jasa keuangan dapat diukur dengan jumlah kantor perbankan dan jumlah ATM yang tersebar di suatu wilayah, sedangkan penggunaan diukur dengan jumlah deposit dan kredit yang disalurkan (World Bank 2009). Kedua konsep ini telah di rangkum oleh Sarma ke dalam satu konsep yaitu Indeks Inklusi Keuangan atau Index of Financial Inclusion. Indeks ini digunakan untuk mengukur keinklusifan sistem keungan di suatu negara. Perhitungan indeks inklusi keuangan yang dikembangkan oleh Sarma (2011) berdasarkan tiga dimensi, yaitu penetrasi perbankan, ketersediaan jasa perbankan, dan penggunaan jasa perbankan.

a. Penetrasi Perbankan

Sistem keuangan yang inklusif harus memiliki pengguna sebanyak mungkin. Oleh karena itu sistem keuangan harus menjangkau secara luas di antara penggunanya. Ukuran populasi yang menakses bank, misalkan proporsi populasi yang memiliki rekening di bank adalah sebuah ukuran dari penetrasi perbankan. Penetrasi perbankan merupakan indikator utama dalam inklusi keuangan.

b. Ketersediaan jasa keuangan Dalam sistem keuangan yang inklusif, jasa keuangan harus tersedia bagi semua pengguna. Indikator ketersediaan ini adalah jumlah outlet (kantor 
cabang, ATM, dll). Ketersediaan jasa dapat diindikasikan dengan jumlah cabang lembaga keuangan atau jumlah ATM (Aoutomatic Teller Machine). Saat ini ATM memiliki peranan yang cukup penting bagi jasa perbankan dalam melayani nasabahnya. Selain memberikan kemudahan dalam mengambil uang tunai, ATM juga dapat digunakan untuk pembayaran. Dengan adanya kantor cabang dan ATM, masyarakat dengan mudah menjangkau jasa keuangan. Selain ATM, di beberapa negara telah menggunakan mobile bangking dan internet banking dalam melayani nasabahnya.

c. Penggunaan jasa perbankan Meskipun memiliki akses terhadap jasa keuangan, masih terdapat sekelompok orang belum dapat memanfaatkan keberadaan jasa keuangan. Hal tersebut dapat dikarenakan beberapa alasan diantaranya, jauhnya outlet bank atau memiliki pengalaman buruk dengan penyedia jasa. Oleh karena itu, memiliki rekening tidak cukup untuk menunjukkan sistem keuangan yang inklusif, namun juga harus dapat digunakan. Kegunaan tersebut diantaranya dapat dalam bentuk kredit, deposit, pembayaran, remitansi, dan transfer.

\section{Faktor-Faktor yang Mempengaruhi Inklusi Keuangan}

Penelitian Sarma dan Pais (2011) menganalisis bagaimana pembangunan ekonomi dapat mempengaruhi inklusi keuangan di suatu negara berdasarkan data dari 49 negara pada tahun 2004. Dari hasil perhitungan korelasi antara indeks inklusi keuangan dengan indeks pembangunan manusia, dapat disimpulkan secara umum terdapat hubungan antara inklusi keuangan dengan pembangunan manusia. Selain itu, dalam penelitian tersebut juga meregresikan inklusi keuangan dan indikator pembangunan dengan menggunakan metode OLS dimana peubah respon dari persamaan regresi yang digunakan merupakan transformasi logit dari indeks inklusi keuangan (IIK), yaitu:

$$
\mathrm{Y}=\ln \left(\frac{\mathrm{IIK}}{1-\mathrm{IIK}}\right)
$$

Dan persamaan umum yang digunakan dalam penelitian tersebut adalah:

$$
\mathrm{Y}=\mathrm{a}_{0}+\mathrm{a}_{1} \mathrm{X}_{1}+\mathrm{a}_{2} \mathrm{X}_{2}+\ldots+\mathrm{a}_{\mathrm{n}} \mathrm{X}_{\mathrm{n}}+\varepsilon
$$

Dimana $\mathrm{X}_{1}, \mathrm{X}_{2}, \mathrm{X}_{\mathrm{n}}$ adalah peubah bebas dan $\varepsilon$ adalah error term.

Hasil penelitian menunjukkan tingkat pembangunan manusia dapat mempengaruhi inklusi keuangan. Negara yang memiliki GDP per kapita rendah, ketimpangan pendapatan yang tinggi, tingkat melek huruf dan urbanisasi yang rendah menunjukkan rendahnya jaminan dalam mengakses sektor keuangan. Ketersediaan informasi yang dicerminkan oleh panjang jalan, penggunaan telepon dan internet juga memiliki peranan penting dalam meningkatkan inklusi keuangan. Dari peubah perbankan, proporsi non performing assets dan capital asset ratio (CAR) memiliki hubungan negatif dengan inklusi keuangan. Sedangkan kepemilikan asing maupun pemerintah di sektor perbankan, dan suku bunga tidak memiliki keterkaitan dengan inklusi keuangan. 
Tidak jauh berbeda dengan hasil penelitian yang dilakukan oleh Wachira dan Kihiu (2012) terkait pengaruh literasi keuangan terhadap akses jasa keuangan di Kenya pada tahun 2009, bahwa akses terhadap jasa keuangan tidak hanya dipengaruhi oleh tingkat literasi keuangan tetapi lebih besar dipengaruhi oleh tingkat pendapatan, jarak dari bank, usia, status perkawinan, jenis kelamin, ukuran rumah tangga, dan tingkat pendidikan. Hasil penelitian Beck et al. (2006) di 99 negara pada tahun 2003-2004 menunjukkan bahwa faktor yang menentukan jangkauan sektor keuangan sama dengan faktor yang menentukan kedalaman sektor keuangan. Faktor-faktor tersebut adalah tingkat dari pembangunan yang diproksikan dengan GDP per kapita, kualitas isntitusi yang diproksikan dengan governance index, serta infromasi kredit yang diproksikan dengan credit information index. Van der Werff et al. (2013), dalam penelitiannya di 31 negara OECD tahun 2011, menunjukkan bahwa faktor yang mempengaruhi proposri populasi yang mengakses perbankan adalah ketimpangan pendapatan, jumlah ATM dan bank per 100.000 populasi, tingkat kepercayaan masyarakat terhadap institusi yang diproksikan dengan corruption index dan GNI per kapita.

Inklusi keuangan juga dipengaruhi oleh perkembangan teknologi. Andrianaivo dan Kpodar (2012) menganalisis 44 negara di benua Afrika dengan menggunakan data tahun 19882007 terkait hubungan telepon seluler, inklusi keuangan dan pertumbuhan ekonomi. Hasil penelitian tersebut menjelaskan bahwa pengembangan telepon seluler berkontribusi terhadap pertumbuhan ekonomi di Afrika. Selain itu, inklusi keuangan yang diukur dengan jumlah tabungan dan pinjaman per kapita menjadi salah satu jalur transmisi dari perkembangan telepon seluler terhadap pertumbuhan.

\section{Pembangunan Sektor Keuangan dan Pemerataan Pendapatan}

Tiwari et al. (2013) meneliti terkait dampak pembangunan sektor keuangan terhadap ketimpangan pendapatan desa-kota di India dengan menggunakan data tahunan dari tahun 1965 sampai 2008. Metode yang digunakan untuk menganalisis hubungan jangka panjang antar variabel dalam penelitian adalah pendekatan ARDL. Hasil penelitiannya menunjukkan dalam jangka panjang pembangunan di sektor keuangan dan kebijakan pemerintah dalam meningkatkan pertumbuhan ekonomi dapat mengurangi ketimpangan pendapatan desa-kota di India.

Analisis terkait dampak pembangunan dan liberalisasi keuangan terhadap ketimpangan pendapatan di India dilakukan oleh Ang (2010) menggunakan metode ARDL dengan tahun dasar analisis 1951-2004. Pertumbuhan GDP per kapita dan pembangunan sektor keuangan, yang dicerminkan dengan perluasan penyebaran perbankan, dapat mengurangi ketimpangan pendapatan di India.

Beck et al. (2007) menganalisis terkait dampak pembangunan sektor keuangan terhadap distribusi pendapatan dan pendapatan masyarakat miskin menggunakan data dari 72 negara tahun 1960-2005. Metode yang digunakan dalam penelitian tersebut adalah GMM. Penelitian tersebut menemukan bahwa pembangunan sektor keuangan membantu masyarakat miskin. Pembangunan sektor keuangan yang semakin besar mendorong pendapatan orang miskin tumbuh lebih cepat dari pertumbuhan rata-rata GDP 
per kapita sehingga ketimpangan pendapatan semakin rendah. Sebesar $60 \%$ dari pembangunan sektor keuangan berdampak pada pertumbuhan agregat dan $40 \%$ terhadap pengurangan ketimpangan pendapatan.

\section{METODE PENELITIAN}

\section{Jenis dan Sumber Data}

Data yang digunakan dalam penelitian ini adalah data sekunder. Data tersebut bersumber dari Otoritas Jasa Keuangan (OJK), Bank Indonesia, Badan Pusat Statistik, dan berbagai sumber yang terkait. Periode analisis dalam penelitian ini adalah tahun 20072011 dengan cross section dari 33 provinsi di Indonesia.

\section{Metode Analisis Data}

\section{Analisis Deskriptif}

Analisis deskriptif digunakan untuk menggambarkan keadaan secara umum dan perkembangan inklusi keuangan serta ketimpangan pendapatan yang terjadi di berbagai provinsi di Indonesia.

\section{Indeks Inklusi Keuangan}

Indeks inklusi keuangan merupakan ukuran untuk tingkat inklusi keuangan. Indeks inklusi keuangan ini akan digunakan untuk mengukur tingkat inklusi keuangan di 33 provinsi di Indonesia dari tahun 2007 sampai dengan tahun 2011. Perhitungan indeks inklusi keuangan dalam penelitian ini mengikuti konsep perhitungan yang telah dilakukan oleh Sarma (2012). Indeks inklusi keuangan ini mencakup tiga dimensi yaitu dimensi penetrasi perbankan, ketersediaan jasa perbankan, dan penggunaan jasa perbankan. Indeks inklusi keuangan dapat dihitung jika masing-masing dimensi telah dihitung nilai indeks dimensi. Indeks dari setiap dimensi, $d_{i}$, dapat dihitung dengan menggunakan persamaan berikut:

$\mathrm{d}_{\mathrm{i}}=\mathrm{w}_{\mathrm{i}} \frac{\mathrm{A}_{\mathrm{i}}-\mathrm{m}_{\mathrm{i}}}{\mathrm{M}_{\mathrm{i}}-\mathrm{m}_{\mathrm{i}}} ; \mathrm{i}=1,2,3$

Dimana:

$w_{i}=$ bobot untuk dimensi i, $0 \leq w_{i} \leq 1$

$A_{i}=$ nilai terkini dari peubah $\mathrm{i}$

$m_{i}=$ nilai minimum (batas bawah) dari peubah i

$M_{i}=$ nilai maksimum (batas atas) dari peubah i

Semakin tinggi nilai indeks suatu dimensi, samakin tinggi pula pencapaian di dalam dimensi tersebut. Misalkan, semakin tinggi indeks dimensi ketersediaan suatu provinsi, semakin tinggi pula jumlah bank yang dapat dijangkau masyarakat di provinsi tersebut. Untuk menghitung indeks setiap dimensi memerlukan bobot. Bobot ditentukan berdasarkan seberapa besar dimensi tersebut dapat mempengaruhi inklusi keuangan. Dalam penelitian ini, seluruh dimensi diasumsikan memiliki peranan yang sama penting dalam menentukkan tingkat inklusi keuangan, sehingga masing-masing dimensi memiliki bobot sebesar 1.

Selain menentukan bobot, untuk menghitung indeks setiap dimensi inklusi keuangan memerlukan batas atas dan batas bawah dari setiap indikator. Batas atas maupun batas bawah harus dijadikan nilai tetap. Batas bawah atau nilai minimum $\left(m_{i}\right)$ setiap dimensi dalam penelitian ini adalah 0 . Sedangkan untuk menentukan batas atas atau nilai maksimum $\left(M_{i}\right)$ setiap indikator, ditentukan oleh sebaran masing-masing indikator.

Sebagaimana penjelasan sebelumnya, dimensi inklusi keuangan 
yang akan diukur terdiri dari tiga dimensi. Dimensi yang pertama adalah penetrasi perbankan yang menggambarkan banyaknya pengguna jasa perbankan. Indikator yang menggambarkan dimensi ini adalah jumlah rekening deposit. Dalam penelitian ini, indikator yang digunakan untuk dimensi penetrasi perbankan adalah jumlah rekening deposit di bank umum konvensional di setiap provinsi di Indonesia dibagi dengan jumlah populasi dewasa di provinsi tersebut.

Dimensi kedua dari inklusi keuangan adalah ketersediaan jasa perbankan yang manggambarkan jangkauan perbankan kepada masyarakat. Indikator yang menggambarkan dimensi ini dapat berupa outlet dari perbankan misalkan jumlah kantor cabang atau ATM yang tersebar di suatu wilayah. Dalam penelitian ini, indikator yang digunakan untuk dimensi ketersediaan jasa perbankan adalah jumlah kantor cabang bank umum konvensional di setiap provinsi dibandingkan dengan jumlah populasi dewasa di provinsi tersebut.

Dimensi ketiga dari inklusi keuangan adalah kegunaan jasa perbankan yang menggambarkan manfaat jasa perbankan yang dirasakan oleh masyarakat. Indikator yang digunakan untuk menggambarkan dimensi ini dapat berupa jumlah tabungan, kredit, remitansi, asuransi, dan jasa lainnya yang ditawarkan oleh perbankan. Namun, untuk mempermudah dalam perhitungan, indikator yang digunakan dalam penelitan ini adalah jumlah Dana Pihak Ketiga (DPK), proksi dari jumlah tabungan, dan kredit yang disalurkan bang umum konvensional di setiap provinsi dibagi dengan PDRB provinsi tersebut. Untuk perhitungan indikator dimensi ketiga setiap provinsi pada tahun t, yaitu kegunaan menggunakan rumus:

kegunaan $=\frac{\text { tabungan }+ \text { kredit }}{\text { PDRB }}$

Ketiga dimensi inklusi keuangan beserta indikator yang digunakan dalam penelitian ini dirangkum dalam Tabel 2.

Tabel 2 Indikator yang digunakan untuk Perhitungan IIK

\begin{tabular}{llll}
\hline Dimensi & Bobot & $\begin{array}{l}\text { Batas } \\
\text { Bawah } \\
\left(m_{i}\right)\end{array}$ & $\begin{array}{l}\text { Batas Atas } \\
\left(M_{i}\right)\end{array}$ \\
\hline $\begin{array}{l}\text { Penetrasi } \\
\text { Perbankan } \\
\left(\mathrm{d}_{\mathrm{p}}\right)\end{array}$ & 1 & 0 & 0,1605461126 \\
$\begin{array}{l}\text { Ketersediaan } \\
\text { Jasa }\end{array}$ & 1 & 0 & 0,0000817470 \\
$\begin{array}{l}\text { Keuangan } \\
\left(\mathrm{d}_{\mathrm{a}}\right)\end{array}$ & & & \\
$\begin{array}{l}\text { Kegunaan } \\
\left(\mathrm{d}_{\mathrm{u}}\right)\end{array}$ & 1 & 0 & 5,9153797962 \\
\hline
\end{tabular}

Persamaan (3) akan menghasilkan nilai $0<d_{i}<1$. Semakin tinggi nilai $\mathrm{d}_{\mathrm{i}}$, semakin tinggi pula perolehan provinsi di dimensi i. Jika terdapat 3 dimensi dari inklusi keuangan yang dihitung, yaitu $p$ untuk penetrasi, $a$ untuk ketersediaan, dan $u$ untuk penggunaan, maka perolehan suatu provinsi dari dimensi tersebut direpresentasikan dengan titik $\mathrm{X}=\left(d_{p}, d_{a}, d_{u}\right)$ pada ruang 3-dimensi (Gambar 2). Dalam ruang 3dimensi, titik $\mathrm{O}=(0,0,0$,$) menunjukkan$ titik kondisi inklusi keuangan yang buruk, sedangkan titik $\mathrm{W}=\left(w_{p}, w_{a}, w_{u}\right)$ menunjukkan kondisi inklusi keuangan yang ideal dari setiap dimensi.

Letak titik $\mathrm{X}, \mathrm{O}$, dan $\mathrm{W}$ merupakan faktor penting dalam mengukur tingkat inklusi keuangan provinsi. Semakin besar jarak antara titik $\mathrm{O}$ dengan titik $\mathrm{X}$, semakin tinggi pula tingkat inklusi keuangan. Semakin kecil jarak antara titik X dengan titik W, semakin tinggi tingkat inklusi keuangan. Kedua jarak tersebut dinormalisasi dengan jarak antara $\mathrm{W}$ 
dan $\mathrm{O}$ agar nilainya antara 0 dan 1 . Oleh karena itu, nilai indeks inklusi keuangan akan berada antara 0 dan 1 . Semakin tinggi nilai indeks, sistem keuangan semakin inklusif.

Jika jarak antara titik $\mathrm{O}$ dengan titik $\mathrm{X}$ dilambangkan dengan $\mathrm{X}_{1}$, yaitu:

$\mathrm{X}_{1}=\frac{\sqrt{\mathrm{d}_{\mathrm{p}}^{2}+\mathrm{d}_{\mathrm{a}}^{2}+\mathrm{d}_{\mathrm{u}}^{2}}}{\sqrt{\mathrm{w}_{\mathrm{p}}^{2}+\mathrm{w}_{\mathrm{a}}^{2}+\mathrm{w}_{\mathrm{u}}^{2}}}$

dan jarak antara titik $\mathrm{X}$ dengan titik $\mathrm{W}$ dilambangkan dengan $\mathrm{X}_{2}$,

$\mathrm{X}_{2}=1-\frac{\sqrt{\left(\mathrm{w}_{\mathrm{p}}-\mathrm{d}_{\mathrm{p}}\right)^{2}+\left(\mathrm{w}_{\mathrm{a}}-\mathrm{d}_{\mathrm{a}}\right)^{2}+\left(\mathrm{w}_{\mathrm{u}}-\mathrm{d}_{\mathrm{u}}\right)^{2}}}{\sqrt{\mathrm{w}_{\mathrm{p}}^{2}+\mathrm{w}_{\mathrm{a}}^{2}+\mathrm{w}_{\mathrm{u}}^{2}}}$

Maka nilai indeks inklusi keuangan adalah rata-rata keduanya,

$\mathrm{IIK}=\frac{1}{2}\left[\mathrm{X}_{1}+\mathrm{X}_{2}\right]$

Jika digambarkan ke dalam ruang tiga dimensi, maka indeks inklusi keuangan adalah sebagai berikut:

Ketersediaan

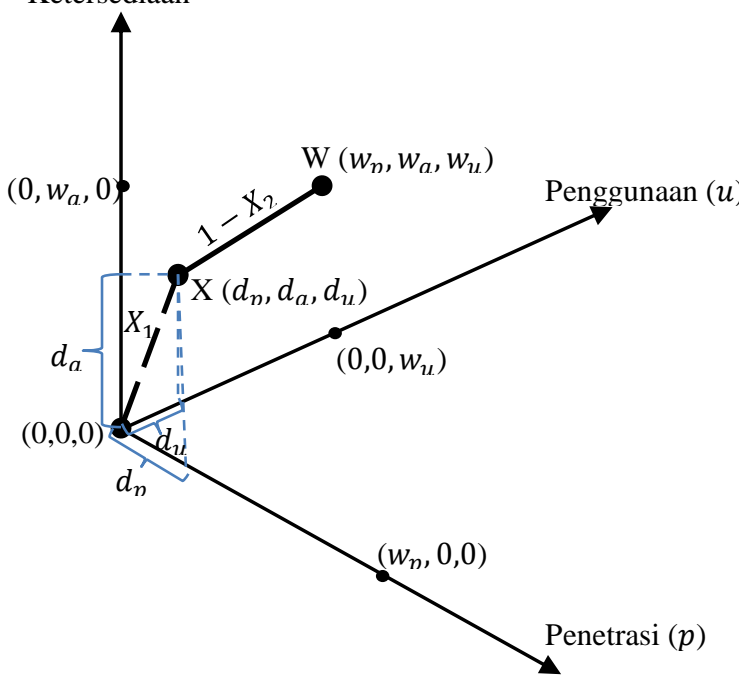

Gambar 2 Penjelasan secara Grafik dari Tiga Dimensi IIK

Sumber : Sarma (2012)

Setelah masing-masing indeks dari ketiga dimensi inklusi keuangan setiap provinsi dihitung, indeks inklusi keuangan setiap provinsi dapat dihitung.
Dengan bobot masing-masing dimensi sebesar 1 , batas bawah setiap dimensi 0 , dan batas atas setiap indikator yang telah ditentukan dari sebaran masingmasing indikator, Indeks dari inklusi keuangan dari provinsi $\mathrm{K}$ dapat dihitung dengan:

$\mathrm{IIK}=\frac{1}{2}\left[\frac{\sqrt{\mathrm{p}_{\mathrm{k}}^{2}+\mathrm{a}_{\mathrm{k}}^{2}+u_{\mathrm{k}}^{2}}}{\sqrt{3}}+\left(1-\frac{\sqrt{\left(1-\mathrm{p}_{\mathrm{k}}\right)^{2}+\left(1-\mathrm{a}_{\mathrm{k}}\right)^{2}+\left(1-\mathrm{u}_{\mathrm{k}}\right)^{2}}}{\sqrt{3}}\right)\right]$

Nilai indeks inklusi keuangan berada antara 0 dan 1 . Nilai IIK=1 menunjukkan provinsi itu memiliki kondisi inklusi keuangan terbaik di antara provinsi yang lain. Sedangkan nilai $\mathrm{IIK}=0$ menunjukkan provinsi tesebut memiliki kondisi inklusi keuangan paling buruk. Tingkat inklusi keuangan semakin baik jika nilai indeks inklusi keuangan mendekati 1.

Dalam penelitian ini, nilai indeks inklusi keuangan akan dikelompokkan ke dalam tiga kategori. Tingkat inklusi keuangan tinggi jika nilai indeks inklusi keuangan $0,6<$ IIK $\leq 1$, tingkat inklusi keuangan sedang jika nilai indeks inklusi keuangan $0,3 \leq d \leq 0,6$, dan tingkat inklusi keuangan rendah jika nilai indeks $\leq 0,3$.

\section{Faktor-faktor yang Mempengaruhi Inklusi Keuangan}

Faktor-faktor yang mempengaruhi inklusi keuangan diduga dengan regresi panel data. Peubah-Peubah yang digunakan dalam penelitian ini diadopsi dari penelitian-penelitian yang telah ada sebelumnya. Untuk menentukkan faktor yang mempengaruhi iklusi keuangan di Indonesia, model penelitian yang digunakan adalah model dari penelitian Sarma dan Pais (2011). Faktor yang mempengaruhi inklusi keuangan dalam penelitian ini dianalisis melalui dua pendekatan, yaitu faktor sosial ekonomi dan infrastruktur. Masing-masing 
pendekatan akan dilakukan analisis regresi dengan peubah bebas yang berbeda. Peubah respon dari setiap pendekatan dalam penelitian ini adalah nilai indeks inklusi keuangan. Karena nilai indeks inklusi keuangan bersifat kontinu dari 0 sampai 1, maka regresi panel yang digunakan adalah regresi panel tobit. Hayashi (2000) menjelaskan bahwa regresi Tobit disebut juga regresi tersensor, hal ini dikarenakan variabel dependen dari regresi tobit nilainya berada pada rentang tertentu. Berikut model tobit secara umum :

$Y_{t}^{*}=X_{t}^{\prime} \beta_{0}+\varepsilon_{t}, t=1,2, \ldots, n$

$$
Y_{t}= \begin{cases}Y_{t}^{*} & \text { jika } Y_{t}^{*}>c \\ c & \text { jika } Y_{t}^{*} \leq c\end{cases}
$$

Dimana $\varepsilon_{\mathrm{t}} \mid \mathrm{x}_{\mathrm{t}}$ menyebar $N\left(0, \sigma_{0}^{2}\right)$ dan $\left\{\mathrm{Y}_{\mathrm{t}}, \mathrm{X}_{\mathrm{t}}\right\}(\mathrm{t}=1,2, \ldots, \mathrm{n})$. Model tobit juga dapat juga ditulis:

$\mathrm{Y}_{\mathrm{t}}^{*}=\max \left\{\mathrm{X}_{\mathrm{t}}^{\prime} \beta_{0}+\varepsilon_{\mathrm{t}}, \mathrm{c}\right\}$

Dalam mengestimasi variabel dengan menggunakan model tobit digunakan metode Maximum Likelihood Estimation (Hansen, 2004). Untuk menentukan likelihood, variabel tersensor yang diobservasi memiliki probabilitas:

$$
\begin{aligned}
\mathrm{P}\left(\mathrm{y}_{\mathrm{i}}=0 \mid \mathrm{x}_{\mathrm{i}}\right) & =\mathrm{P}\left(\mathrm{y}_{\mathrm{i}}^{*}<0 \mid \mathrm{x}_{\mathrm{i}}\right) \\
& =\mathrm{P}\left(\mathrm{x}_{\mathrm{i}}^{\prime} \beta+\mathrm{e}_{\mathrm{i}}<0 \mid \mathrm{x}_{\mathrm{i}}\right) \\
& =\mathrm{P}\left(\frac{\mathrm{e}_{\mathrm{i}}}{\sigma}<-\frac{\mathrm{x}_{\mathrm{i}}^{\prime} \beta}{\sigma} \mid \mathrm{x}_{\mathrm{i}}\right) \\
& =\Phi\left(\frac{\mathrm{x}_{\mathrm{i}}^{\prime} \beta}{\sigma}\right) \ldots \ldots \ldots . . .
\end{aligned}
$$

Tujuan utama dari pembentukan model adalah untuk memilih variabel yang sesuai dan memberikan hasil yang terbaik dalam menjelaskan masalah yang dihadapi. Semakin banyak variabel yang masuk kedalam model, maka semakin kompleks model yang dihasilkan. Begitu juga semakin banyak variabel prediktor yang diperlukan untuk menduga respon. Hal ini diatasi dengan menyeleksi variabel yang masuk ke model secara bertahap agar didapatkan model yang layak digunakan.

\begin{tabular}{|c|c|c|}
\hline Indikator & Lambang & $\begin{array}{l}\text { Peubah dan } \\
\text { satuan }\end{array}$ \\
\hline \multirow{7}{*}{$\begin{array}{l}\text { Sosial } \\
\text { Ekonomi }\end{array}$} & Pdrb & PDRB atas dasar \\
\hline & & harga konstan \\
\hline & & 2000 (Milyar \\
\hline & & Rupiah) \\
\hline & Pengangguran & $\begin{array}{l}\text { Tingkat } \\
\text { pengangguran } \\
\text { (persen) }\end{array}$ \\
\hline & Melek_huruf & $\begin{array}{l}\text { Angka melek } \\
\text { huruf (persen) }\end{array}$ \\
\hline & Gini & $\begin{array}{l}\text { Koefisien gini } \\
\text { (indeks) }\end{array}$ \\
\hline \multirow[t]{3}{*}{ Infrastuktur } & Rasio_jalan & $\begin{array}{l}\text { Rasio panjang } \\
\text { jalan dengan } \\
\text { kondisi baik dan } \\
\text { sedang terhadap } \\
\text { luas wilayah } \\
(1 / \mathrm{km})\end{array}$ \\
\hline & Internet & $\begin{array}{l}\text { Persentase } \\
\text { penduduk } \\
\text { pengguna } \\
\text { internet (persen) }\end{array}$ \\
\hline & Ponsel & $\begin{array}{l}\text { Persentase rumah } \\
\text { tangga yang } \\
\text { memiliki telepon } \\
\text { seluler (persen) }\end{array}$ \\
\hline
\end{tabular}

Tabel 3 Peubah Bebas yang Digunakan untuk Faktor-faktor yang Mempengaruhi Inklusi Keuangan di Indonesia

Persamaan umum yang digunakan dalam penelitian ini untuk faktor sosial ekonomi adalah:

$$
\begin{aligned}
\mathrm{Y}_{\mathrm{it}}= & \mathrm{a}_{0}+\mathrm{a}_{1} \text { pdrb }_{\mathrm{it}}+\mathrm{a}_{2} \text { pengangguran }_{\mathrm{it}} \\
& +\mathrm{a}_{3} \text { melek_huruf }_{\mathrm{it}}+\mathrm{a}_{4} \text { gini }_{\mathrm{it}}+\varepsilon_{\mathrm{it}} \ldots
\end{aligned}
$$

Sedangkan model penelitian untuk faktor infrastuktur adalah:

$\mathrm{Y}_{\mathrm{it}}=\mathrm{b}_{0}+\mathrm{b}_{1}$ internet $_{\mathrm{it}}+\mathrm{b}_{2}$ ponsel $_{\mathrm{it}}$ 


$$
+\mathrm{b}_{3} \text { rasio_jalan }{ }_{\mathrm{it}}+\varepsilon_{\mathrm{it}}
$$

Dimana Y merupakan nilai indeks inklusi keuangan, i adalah identsitas yaitu provinsi, dan t menunjukkan tahun analisis. a merupakan koefisien yang diestimasi, sedangkan $\varepsilon_{i t}$ merupakan error term. Peubah bebas yang akan digunakan dalam analisis ini diadopsi dari beberapa penelitian sebelumnya. Peubah yang akan digunakan dirangkum dalam Tabel 3.

\section{Hubungan Inklusi Keuangan dengan Pemerataan Pendapatan}

Salah satu faktor yang dapat mempengaruhi inklusi keuangan adalah pemerataan pendapatan. Pendapatan yang semakin merata dapat memperluas kesempatan masyarakat dalam menjangkau akses perbankan. Terjadinya peningkaan pendapatan dikalangan masyarakat berpendapatan rendah, memberikan peluang bagi mereka untuk menggunakan jasa perbankan sehingga jasa perbankan tidak hanya dinikmati oleh masyarakat yang berpendapatan tinggi saja. Beberapa penelitian juga menunjukkan bahwa salah satu yang mempengaruhi inklusi keuangan adalah pemerataan pendapatan.

Tetapi terdapat kemungkinan bahwa tingkat inklusi keuangan juga mempengaruhi ketimpangan pendapatan di Indonesia. Sektor perbankan yang semakin inklusif dapat menciptakan pertumbuhan yang merata sehingga pemerataan pendapatan juga akan semakin merata. Masyarakat yang awalnya tidak menggunakan jasa perbankan, kemudian mengakses dan menggunakan jasa perbakan, memiliki kesempatan untuk memperbaiki kondisi hidup menjadi lebih baik. Kesejahteraan masyarakat yang semakin meningkat memiliki kontribusi bagi pertumbuhan perekonomian. Oleh karena itu, perlu dilakukan analisis lebih lanjut terkait hubungan inklusi keuangan dan pemerataan di Indonesia.

Analisis yang dilakukan untuk mengetahui hubungan inklusi keuangan dengan pemerataan pendapatan akan digunakan analisis Kausalitas Granger pada panel data. Persamaan umum kausalitas grager pada panel data (Konya 2006) adalah sebagai berikut:

$\mathrm{Y}_{\mathrm{i}, \mathrm{t}}=\alpha+\sum_{\mathrm{k}=1}^{k} \gamma_{\mathrm{i}}^{(\mathrm{k})} \mathrm{Y}_{\mathrm{i}, \mathrm{t}-\mathrm{k}}+\sum_{\mathrm{k}=1}^{\mathrm{k}} \beta_{\mathrm{i}}^{(\mathrm{k})} \mathrm{X}_{\mathrm{i}, \mathrm{t}-\mathrm{k}}+\varepsilon_{\mathrm{i}, \mathrm{t}}$

Di mana $\mathrm{Y}=$ peubah respon; $\mathrm{X}=$ peubah penjelas ; $\mathrm{i}=1, \ldots, \mathrm{N}$ jumlah individu; $\mathrm{t}=1, \ldots, \mathrm{N}$ periode waktu; $\alpha=$ intersep ; $\mathrm{k}=1, \ldots, \mathrm{k}$ lag $; \varepsilon=$ error term.

Analisis kausalitas granger pada panel data dilakukan melalui tiga tahap. Tahapan pertama adalah menguji stasioneritas data dengan unit root test pada panel data. Selanjutnya dilakukan uji kointegrasi untuk melihat apakah ada pengaruh jangka panjang atau tidak. Jika terdapat pengaruh jangka panjang, analisi dilanjutkan dengan analisis VECM. Tetapi, jika tidak terdapat hubungan jangka panjang, analisis dilakukan dengan VAR. Tahapan selanjutnya adalah dilakukan uji kausalitas granger untuk mengetahui hubungan kedua variabel.

\section{PEMBAHASAN}

\section{Tingkat Inklusi Keuangan antar Provinsi di Indonesia}

Indeks inklusi keuangan dibentuk oleh 3 dimensi yaitu penetrasi perbankan, ketersediaan jasa perbankan, dan penggunaan jasa perbankan. Nilai indeks inklusi keuangan dari 33 provinsi di Indonesia dari tahun 2007 sampai dengan 2011 berkisar antara 0,10,3 , meskipun terdapat satu provinsi yang nilainya mencapai $0,8-1$ yaitu DKI 
Jakarta. Pada umumnya nilai indeks inklusi keuangan dari tahun 2007-2011 selalu mengalami peningkatan tetapi peningkatan nilai indeks tidak begitu signifikan. Pada tahun 2007 nilai indeks inklusi keuangan di Indonesia mencapai 0,184 dan meningkat menjadi 0,246 pada tahun 2011 .

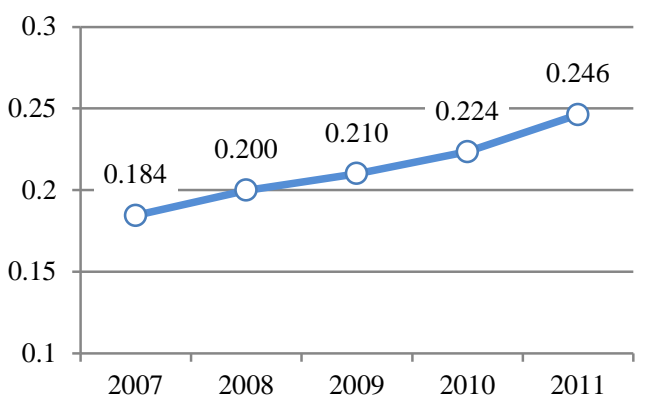

Gambar 3 Indeks Inklusi Keuangan Indonesia Tahun 2007-2011

Seperti yang ditujukan pada Gambar 3, indeks inklusi keuangan di Indonesia mengalami peningkatan dari tahun 2007 sampai dengan tahun 2011. Hal ini menunjukkan bahwa terjadi peningkatan inklusivitas jasa perbankan di Indonesia selama 5 tahun. Adanya peningkatan inklusi keuangan di Indonesia, khususnya jasa perbankan, dikarenakan adanya peningkatan dari setiap dimensi inklusi keuangan yaitu penetrasi perbankan, ketersediaan perbankan, dan penggunaan jasa perbankan di Indonesia. Peningkatan ini juga menggambarkan bahwa akses dan penggunakan jasa perbankan oleh masyarakat Indonesia, khususnya bank umum konvensional, mengalami peningkatan. Hal ini seiring dengan semakin berkembangnya sektor perbankan di Indonesia.

Tabel 4 Nilai Dimensi Indeks Inklusi Keuangan Indonesia Tahun 2007-2011

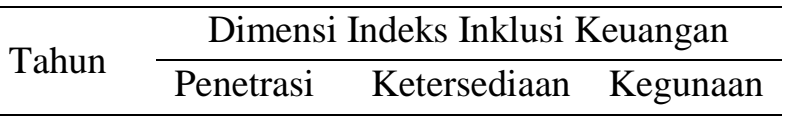

\begin{tabular}{llll} 
& perbankan & Perbankan & \\
\hline 2007 & 0,103 & 0,217 & 0,224 \\
2008 & 0,107 & 0,223 & 0,258 \\
2009 & 0,109 & 0,234 & 0,274 \\
2010 & 0,112 & 0,232 & 0,311 \\
2011 & 0,114 & 0,250 & 0,355 \\
\hline
\end{tabular}

Tabel 4 menunjukkan nilai setiap dimensi yang dicapai oleh Indonesia. Dalam penelitian ini, masing-masing dimensi dibagi kedalam 3 kategori, yaitu tinggi $(0,6<d \leq 1)$, sedang $(0,3 \leq$ $d \leq 0,6)$, dan rendah $(\leq 0,3)$. Nilai indeks dimensi penetrasi perbankan di Indonesia paling kecil jika dibandingkan dengan ketersediaan jasa perbankan dengan kegunaan, yaitu ratarata sebesar 0,1. Dimensi penetrasi perbankan di Indonesia juga tergolong rendah, artinya, meskipun jumlah rekening di Indonesia mencapai 2,9 juta unit, orang yang mengakses jasa perbankan di Indonesia masih rendah. Dari 100.000 pupulasi dewasa di Indonesia hanya 1830 orang yang memiliki rekening di bank umum konvensional pada tahun 2011 (BI 2014). Dimensi ketersediaan perbankan di Indonesia juga tergolong ke dalam kategori rendah karena nilainya berkisar pada 0,2. Meskipun jumlah kantor cabang di Indonesia pada tahun 2011 mencapai 3.280 unit, tetapi jumlah ini belum mampu melayani seluruh masyarakat di Indonesia. Dari 1.000.000 populasi dewasa di Indonesia hanya dilayani oleh 20 kantor cabang bank umum konvensional. Sama dengan dimensi ketersediaan, dimensi kegunaan juga tergolong ke dalam kategori rendah. Meskipun terjadi peningkatan yang relatif lebih besar dari tahun 2007 sebesar 0,2 menjadi 0,3 pada tahun 2011. Peningkatan pada dimensi ini menunjukkan adanya peningkatan pada volume tabungan dan kredit yang 
disalurkan oleh bank umum konvensional terhadap PDB Indonesia.

Berdasarkan Tabel 4, dimensi ketersediaan perbankan lebih tinggi dibandingkan dengan dimensi penetrasi perbankan. Artinya, jumlah kantor cabang relatif lebih banyak, tetapi jumlah orang yang memiliki rekening masih sangat rendah. Rendahnya penetrasi perbankan dapat disebabkan oleh beberapa kemungkinan. Pertama, meskipun perbankan tidak banyak memiliki nasabah tetapi nasabah yang jumlahnya relatif sedikit melakukan transaksi dengan volume relatif besar. Besarnya volume transaksi dapat dilihat dari dimensi ketiga yaitu kegunaan perbankan. Kedua, rendahnya dimensi penetrasi perbankan dikarenakan pemberian bobot yang sama dalam perhitungan indeks dimensi. Penetrasi perbankan seharusnya diberi bobot lebih besar dibanding dengan dimensi lainnya, karena jumlah pengguna perbankan merupakan indikator penting dari jasa keuangan yang inklusif. Jasa keuangan akan semakin inklusif jika pengguna jasa tersebut lebih banyak.

\section{Penetrasi Perbankan}

Dimensi pertama dari inklusi keuangan adalah penetrasi perbankan yang menggambarkan banyaknya pengguna jasa perbankan. Jasa keuangan semakin inklusif jika pengguna jasa perbankan semakin banyak. Salah satu ukuran dari dimensi ini adalah jumlah rekening deposit yang ada di perbankan. Proksi dari penetrasi perbankan dalam penelitian ini digambarkan dengan jumlah rekening deposit yang terdapat di BUK.

Hampir seluruh provinsi di Indonesia memiliki nilai dimensi penetrasi perbankan rendah kecuali Jakarta. Penetrasi perbankan di Jakarta digolongkan ke dalam kategori tinggi, yaitu berkisar antara 0,8-1 selama tahun
2007 sampai dengan tahun 2011. Jumlah rekening di Provinsi Jakarta mencapai 1.050.707 unit pada tahun 2011, meningkat sebesar 15\% dari tahun 2007 yang berjumlah 916.467 unit. Adanya peningkatan jumlah rekening di perbankan menunjukkan pengguna jasa bank umum konvensional di Jakarta semakin meningkat. Selain jumlah pengguna jasa perbankan semakin banyak, peningkatan ini juga dapat disebabkan oleh individu yang awalnya hanya memiliki satu rekening menjadi lebih dari satu rekening. Selain Jakarta, provinsi yang memiliki jumlah rekening cukup banyak adalah Jawa Barat, Jawa Timur, dan Jawa Tengah. Jawa Barat memiliki 290.000 unit rekening, Jawa Tengah memiliki 180.000 unit rekening, sedangkan Jawa Timur memiliki 330.000 unit rekening. Namun, setelah dibagi dengan penduduk dewasa yang ada, nilai dimensi ini menjadi sangat kecil. Jumlah populasi dewasa yang besar yaitu lebih dari 20 juta jiwa, menyebabkan nilai dimensi penetrasi perbankan di ketiga provinsi ini menjadi rendah, yaitu di bawah 0,1 .

Tingginya penetrasi perbankan di Jakarta disebabkan oleh aktivitas perekonomian di Jakarta juga tinggi. Jakarta merupakan pusat kegiatan perekonomian Indonesia. Jakarta memberi sumbangan tertinggi di antara provinsi lainnya terhadap perekonomian Indonesia yaitu sebesar 16,3 persen (BPS 2014). Baik usaha skala kecil maupun usaha besar berskala industri berkembang di provinsi tersebut. Menurut Dinas Koperasi dan UMKM Provinsi Jakarta, jumlah UMKM yang terdaftar mencapai 7.343 unit pada tahun 2014. Usaha ini membutuhkan modal untuk keberlangsungan usahanya. Salah satu sumber modal bagi UMKM adalah kredit yang ditawarkan oleh perbankan. Selain sebagai sumber 
modal, jasa perbankan dibutuhkan sebagai media transaksi yang cepat sehingga usaha berjalan lebih efisien. Adanya jasa perbankan ini dapat mengurangi biaya transaksi yang harus dikeluarkan oleh pengusaha. Selain itu, tingginya penetrasi perbankan di Jakarta disebabkan banyaknya individu atau perusahaan yang memiliki rekening di lebih dari satu bank. Banyaknya UMKM di Jakarta yang mengakses perbankan mempengaruhi tingginya tingkat penetrasi perbankan di Jakarta.

Sebanyak 32 provinsi di Indonesia memiliki penetrasi perbankan yang rendah. Dari 32 provinsi ini, provinsi dengan penetrasi perbankan yang paling rendah adalah Nusa Tenggara Barat dan Gorontalo. Baik jumlah penduduk dewasa maupun jumlah rekening yang ada di Gorontalo keduanya rendah. Sedangkan di Provinsi Nusa Tenggara Barat, meskipun jumlah rekening jauh lebih banyak dari Gorontalo, jumlah penduduk dewasa di provinsi tersebut juga jauh lebih banyak, akibatnya dimensi penetrasi perbankan di Nusa Tenggara Barat tergolong sangat rendah.

Hampir seluruh provinsi memiliki tren yang meningkat pada dimensi penetrasi perbankan, kecuali Provinsi Bangka Belitung. Pencapaian dimensi penetrasi perbankan Bangka Belitung pada tahun 2007 mencapai 0,2 turun menjadi 0,1 pada tahun 2011. Penurunan nilai indeks dimensi penetrasi perbankan di Bangka Belitung disebabkan penurunan jumlah rekening dan jumlah populasi dewasa di provinsi ini dari tahun 2007 ke tahun 2011.

Kepemilikan rekening bank oleh individu lebih dari satu menyebabkan perhitungan penetrasi perbankan menggunakan jumlah rekening bersifat bias. Namun, sulitnya menghitung jumlah orang yang mengakses perbankan saat ini menjadikan jumlah rekening deposit yang ada diperbankan merupakan proksi terbaik dari dimensi penetrasi perbankan saat ini. Dimensi penetrasi perbankan akan lebih tepat jika diproksikan dengan jumlah individu yang mengakses perbankan.

\section{Ketersediaan Jasa Perbankan}

Dimensi kedua dari inklusi keuangan adalah ketersediaan jasa perbankan. Keberadaan jasa perbankan merupakan hal yang penting dalam keuangan yang inklusif. Indikator yang digunakan untuk dimensi ini adalah jumlah kantor cabang bank umum konvensional. Tersedianya kantor cabang perbankan yang dapat dijangkau oleh masyarakat menunjukkan penyebaran jasa perbankan. Semakin banyak dan semakin luas penyebaran kantor cabang perbankan, maka layanan jasa perbankan yang diberikan semakin tinggi.

Terdapat 8 provinsi yang memiliki kantor cabang bank umum konvensional lebih dari 100 kantor pada tahun 2011, yaitu Jakarta (535), Jawa Barat (369), Jawa Timur (397), Jawa Tengah (300), Sumatera Utara (178), Sulawesi Selatan (121), dan Kalimantan Timur (104). Jumlah kantor cabang yang ada di suatu daerah berkaitan dengan jumlah pengguna jasa perbankan. Jasa perbankan harus mudah dijangkau oleh para pengguna. Namun, banyaknya kantor cabang belum cukup menggambarkan luas penyebaran layanan perbankan. Oleh karena itu, untuk mengetahui berapa banyak individu yang dapat dijangkau oleh perbankan, jumlah kantor cabang yang ada dibagi dengan jumlah populasi dewasa. Setelah dibandingkan dengan jumlah populasi dewasa, banyaknya jumlah kantor cabang belum cukup menjamin perbankan dapat menjangkau masyarakat. Semakin banyak populasi dewasa di suatu daerah, semakin banyak 
pula kantor cabang yang dibutuhkan agar dapat melayani pengguna jasa perbankan.

Nilai dimensi ketersediaan jasa perbankan di Indonesia berkisar antara 0,1 sampai dengan 1. Sebanyak 23 provinsi di Indonesia memiliki nilai dimensi ketersediaan $0,1-0,2$ atau tergolong rendah. Sedangkan provinsi yang termasuk ke dalam kategori sedang sebanyak 9 provinsi, yaitu Kepulauan Riau, Bangka Belitung, Bali, Kalimantan Selatan, Kalimantan Timur, Sulawesi Utara, Maluku, Papua, dan Papua Barat. Provinsi yang tergolong ke dalam dimensi ketersediaan tinggi hanya Provinsi Jakarta. Salah satu penyebab banyaknya kantor cabang bank umum konvensional di Jakarta adalah seluruh bank umum konvensional memiliki kantor cabang di Jakarta. Bank umum konvensional yang tergolong ke dalam bank asing pada umumnya tidak memiliki kantor cabang di luar provinsi Jakarta.

Dimensi ketersediaan di seluruh provinsi mengalami kenaikan dari tahun 2007 ke tahun 2008. Artinya, terjadi peningkatan dalam fasilitas fisik perbankan untuk menjangkau masyarakat. Kalimantan Selatan tergolong dalam kategori rendah pada tahun 2007, kemudian pada tahun 2009 meningkat menjadi kategori sedang, dan Bangka Belitung tergolong dalam kategori rendah pada tahun 2007 meningkat menjadi kategori sedang pada tahun 2008.

Meskipun jumlah kantor cabang bank umum konvensional di pulau jawa tinggi, tetapi nilai indeks ketersediaan di pulau jawa rendah. Sedangkan di Papua, Papua Barat dan beberapa provinsi lainnya jumlah kantor cabang yang tersedia jauh lebih rendah dari pulau jawa, tetapi nilai indeks ketersediannya lebih tinggi dari provinsi yang berada di Pulau Jawa. Jumlah populasi dewasa yang rendah, yaitu sekitar 400 ribu orang, menyebabkan nilai dimensi ketersediaan Papua berada pada kategori sedang, lebih tinggi dari provinsi yang berada di pulau Jawa.

\section{Kegunaan Jasa Perbankan}

Kegunaan dari jasa perbankan merupakan dimensi ketiga dari inklusi keuangan. Banyak orang yang memiliki akses terhadap jasa perbankan tetapi tidak menggunakan jasa tersebut dikarenakan berbagai alasan seperti jarak yang cukup jauh untuk menjangkau bank terdekat, produk yang ditawarkan tidak sesuai dengan kebutuhan, atau memiliki pengalaman yang buruk dengan penyedia jasa. Sehingga kepemilikan rekening saja tidak cukup untuk menggambarkan keinklusifan sistem keuangan. Indikator yang digunakan untuk mengukur dimensi ini adalah jumlah tabungan dan kredit yang disalurkan oleh perbankan. Simpanan dan pinjaman merupakan jasa yang mendasar dari setiap perbankan.

Terdapat 1 provinsi yang dikategorikan tinggi, 2 provinsi dikategorikan sedang, dan 30 provinsi lainnya dikategorikan rendah dalam dimensi kegunaan jasa perbankan. Provinsi dengan tingkat tabungan dan kredit paling tinggi pada tahun 2011 adalah Jakarta. Jumlah DPK yang terhimpun pada tahun 2011 di Jakarta mencapai Rp1.417 triliun dan kredit yang tersalurkan sebesar Rp1.080 triliun. Baik DPK maupun kredit dengan nominal yang sangat besar dikarenakan besarnya nilai transaksi, serta kredit korporasi dicatat di kantor pusat yang terletak di Jakarta. Hal ini dikarenakan di Jakarta banyak berdiri kantor pusat perusahaan besar yang melakukan transaksi di perbankan dengan volume yang cukup besar. Selain kredit korporasi, kredit yang disalurkan perbankan untuk UMKM di 
Jakarta juga relatif tinggi. Berdasarkan data dari Kementerian Koperasi dan UMKM, baki debit kredit yang disalurkan UMKM pada September 2014 mencapai Rp101.505 miliar. Tingginya tingkat tabungan dan kredit di Jakarta menyebabkan nilai dimensi kegunaan Jakarta paling tinggi dengan nilai dimensi rata-rata sebesar 0,8 .

Provinsi yang dikategorikan sedang dalam dimensi kegunaan jasa perbankan adalah provinsi Nusa Tenggara Barat dan Maluku Utara. Jika dibandingkan dengan provinsi yang berada di pulau Jawa ataupun Sumatera, kedua provinsi ini memiliki volume kredit dan deposit yang jauh lebih sedikit. Tetapi, karena PDRB yang kecil dibandingkan dengan penjumlahan kredit yang disalurkan dan tabungan yang terhimpun, nilai dimensi kegunaan jasa perbankan menjadi lebih besar.

\section{Indeks Inklusi Keuangan antar Provinsi}

Dalam penelitian ini, indeks inklusi keuangan dibagi kedalam tiga kategori berdasarkan nilai indeks inklusi keuangannya. Pertama, suatu provinsi dikategorikan sebagai provinsi dengan inklusi keuangan tinggi adalah provinsi yang memiliki indeks inklusi keuangan antara 0,6-1. Provinsi yang memiliki indeks inklusi keuangan antara 0,3-0,6 dikategorikan sebagai provinsi dengan inklusi keuangan sedang, dan provinsi yang memiliki indeks inklusi keuangan dibawah 0,3 dikategorikan sebagai provinsi dengan inklusi keuangan rendah.

Rendahnya tingkat inklusi keuangan di Indonesia dapat disebabkan oleh banyaknya penduduk yang tidak dapat mengakses perbankan. Masyarakat tidak dapat mengakses perbankan karena adanya hambatan geografis Indonesia yang merupakan negara kepulauan sehingga biaya pendirian kantor cabang mahal. Selain itu, persyaratan yang ketat, proses yang kompleks, dan formalitas yang tinggi menjadi hambatan bagi masyarakat untuk mengakses perbankan (BI 2014).

Berdasarkan nilai rata-rata indeks inklusi keuangan, 31 provinsi di Indonesia memiliki kategori inklusi keuangan yang rendah. Dua provinsi lainnya tergolong sedang dan tinggi. Provinsi yang termasuk ke dalam inklusi keuangan yang sedang adalah Kepulauan Riau. Mulanya provinsi ini berada pada posisi rendah, kemudian pada tahun 2009 mengalami peningkatan dan masuk ke dalam posisi sedang. Hal ini karena dimensi ketersediaan perbankan Kepulauan Riau mencapai 0,5 atau pada posisi sedang. Sedangkan Jakarta memiliki inklusi keuangan tertinggi di antara provinsi yang lainnya karena tingginya ketiga dimensi dari inklusi keuangan.

Jika dilihat dari sebaran ketiga dimensi inklusi keuangan, DKI Jakarta jauh lebih tinggi dibandingkan dengan provinsi lainnya. Akibatnya tingkat inklusi keuangan semua provinsi terlihat jauh lebih buruk. Tetapi jika Jakarta dikeluarkan dalam perhitungan, nilai dari indeks inklusi keuangan setiap provinsi overestimate, atau terlalu besar.

Berdasarkan indeks inklusi keuangan, tingkat keinklusifan perbankan di pulau Jawa lebih rendah dari Bali, Kalimantan, Sulawesi, Maluku dan Papua. Rendahnya nilai indeks inklusi keuangan di pulau Jawa dikarenakan jumlah rekening yang terdaftar, jumlah kantor cabang, maupun jumlah DPK dan kredit relatif lebih tinggi, tetapi tidak sebanding dengan jumlah populasi yang ada di pulau Jawa. Selain jumlah populasi dewasa yang sangat tinggi, penduduk provinsi di Pulau Jawa memiliki banyak pilihan jasa keuangan selain bank umum konvensional. 
Rendahnya indeks inklusi keuangan menunjukkan penyebaran dan pemanfaatan jasa perbankan masih rendah. Perbedaan indeks inklusi keuangan antar provinsi di Indonesia menunjukkan masih terjadinya ketimpangan akses jasa perbankan antar provinsi. Selain itu, beberapa provinsi yang memiliki kantor perbankan, rekening deposit, dan tingkat penggunaan perbankan yang cukup tinggi memiliki indeks inklusi keuangan lebih rendah dibandingkan dengan provinsi yang memiliki kantor perbankan, rekening deposit, dan tingkat penggunaan perbankan yang relatif lebih rendah. Indeks inklusi keuangan di Papua, Maluku, Sulawesi, dan Kalimantan lebih tinggi dibandingkan dengan indeks inklusi keuangan di Pulau Jawa. Besarnya indeks di beberapa provinsi tersebut menunjukkan bahwa indikator yang digunakan Sarma dalam menghitung indeks inklusi keuangan belum mampu menangkap fenomena di Indonesia.

\section{Faktor-faktor yang Mempengaruhi Inklusi Keuangan di Indonesia}

Faktor-faktor yang mempengaruhi inklusi keuangan di Indonesia dianalisis menggunakan panel tobit. Baik model dari pendekatan sosial ekonomi, maupuan model dari pendekatan infrastruktur, model yang memiliki nilai statsitik Wald Chi-Square dengan pvalue sebesar 0,000 , artinya tolak $\mathrm{H}_{0}$, bahwa pada tingkat kepercayaan 95 persen paling tidak ada salah satu peubah bebas yang berpengaruh terhadap peubah terikatnya.

Berdasarkan hasil estimasi pendekatan sosial ekonomi, terdapat korelasi antara peubah pengangguran dengan PDRB dan pengangguran dengan melek huruf sehingga peubah pengangguran dikeluarkan dari model.
Ukuran perekonomian dan ketimpangan pendapatan (Gini) signifikan pada taraf nyata $1 \%$. Tetapi, angka melek huruf tetap tidak signifikan.

Tabel 5 Faktor-faktor Mempengaruhi yang Keuangan

(a) Pendekatan Sosial Ekonomi

\begin{tabular}{lll}
\hline Variabel & Koefisien & $\mathrm{p}>|\mathrm{z}|$ \\
\hline Pdrb & $4,46 \mathrm{e}-07$ & $0,006^{*}$ \\
Melek_huruf & 0,0029 & 0,112 \\
Gini & 0,3957 & $0,000^{*}$ \\
_cons & $-0,2215$ & 0,169 \\
\hline Wald Chi-square & 79,17 & \\
Log likelihood & 311,912 & \\
Probability & 0,0000 & \\
\hline
\end{tabular}

(b) Pendekatan Infrastruktur

\begin{tabular}{lll}
\hline Variabel & Koefisien & $\mathrm{p}>|\mathrm{z}|$ \\
\hline Ponsel & 0,0012 & $0,000^{*}$ \\
Rasio_jalan & 0,0019 & 0,897 \\
_cons & 0,1364 & $0,000^{*}$ \\
\hline Wald Chi-square & 267,32 & \\
Log likelihood & 335,126 & \\
Probability & 0,0000 & \\
& & \\
\hline
\end{tabular}

*Signifikan pada taraf nyata $1 \%$,

**signifikan pada taraf nyata $5 \%$,

***signifikan pada taraf nyata $10 \%$

Berdasarkan pendekatan infrastruktur, terdapat korelasi antara peubah jumlah pengguna internet dengan jumlah pengguna telepon seluler sehingga peubah jumlah pengguna internet dikeluarkan dari model. Hasilnya adalah peubah jumlah pengguna telepon seluler sigifikan pada taraf nyata $1 \%$ tetapi rasio panjang jalan dengan luas wilayah tidak signifikan.

Hasil estimasi menunjukkan beberapa peubah signifikan mempengaruhi inklusi keuangan. Hal 
ini dapat dilihat dari p-value masingmasing peubah, dimana jika nilainya kurang dari $\alpha=5$ persen dapat dikatakan bahwa peubah bebas yang dimaksud signifikan secara statistik. Masing-masing peubah yang mempengaruhi inklusi keuangan akan dijelaskan sebagai berikut.

\section{Ukuran Perekonomian}

Ukuran perekonomian $\begin{array}{r}\text { yang } \\ \text { dengan }\end{array}$ PDRB
diproksikan insian
memengaruhi positif terhadap inklusi
keuangan pada taraf nyata 5 persen. Hal
ini dapat dilihat dari koefisien yang
bertanda positif. Jika terjadi
peningkatan PDRB di suatu provinsi,
tingkat inklusi keuangan di provinsi
tersebut juga meningkat. Artinya,
peningkatan PDRB dapat meningkatkan
akses, ketersediaan, dan penggunaan
jasa keuangan terutama bank umum
konvensional di provinsi tersebut.

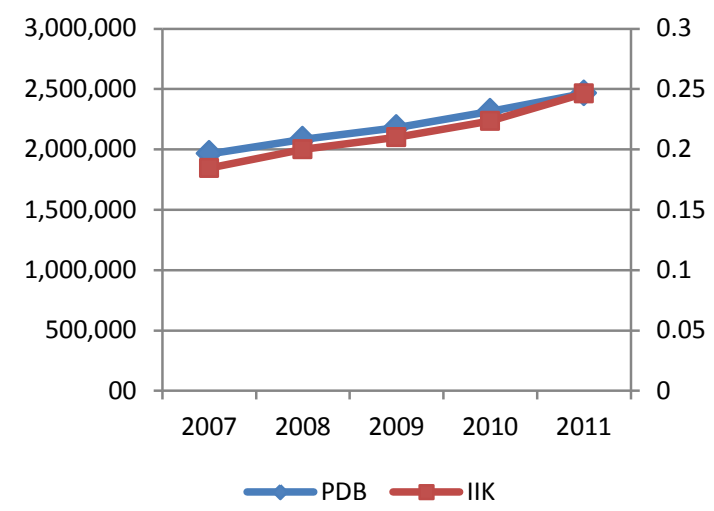

Gambar 4 Laju Pendapatan Domestik Bruto (PDB, Rp Miliar) dan Indeks Inklusi Keuangan (IIK) di Indonesia tahun 2007-2011

Sumber : PDB (BPS 2014), IIK (hasil perhitungan peneliti)

Seluruh provinsi di Indonesia memiliki tren PDRB yang meningkat dari tahun 2007 sampai tahun 2011. Hal ini juga mengakibatkan PDRB
Indonesia selalu mengalami pertumbuhan positif dari tahun ke tahun. Begitu juga dengan tingkat inklusi keuangan setiap provinsi dari tahun 2007 sampai 2011 selalu mengalami peningkatan. Hal ini menunjukkan bahwa seiring dengan peningkatan ukuran perekonomian, inklusi keuangan di Indonesia juga meningkat.

Peningkatan PDRB merupakan salah satu cerminan dari pertumbuhan ekonomi di suatu daerah. Pertumbuhan ekonomi yang positif menunjukkan kinerja perekonomian membaik. Kondisi perekonomian yang baik menjadi signal bagi perbankan untuk memperluas jaringannya sehingga akses perbankan semakin terbuka. Selain itu, peningkatan PDRB juga dapat mencerminkan peningkatan produktivitas masyarakat. Semakin produktif masyarakat dalam berbagai kegiatan perekonomian, maka semakin besar peluang masyarakat untuk meningkatkan pendapatan. Dengan pendapatan yang meningkat, kesempatan masyarakat untuk menggunakan jasa perbankan semakin besar baik untuk menabung, melakukan investasi, ataupun untuk keperluan transaksi lainnya.

\section{Koefisien Gini}

Koefisien gini memengaruhi positif terhadap inklusi keuangan di Indonesia pada taraf nyata 1 persen. Hasil dugaan tidak sesuai dengan hipotesis yang menyatakan gini memengaruhi negatif terhadap inklusi keuangan di Indonesia. Di beberapa negara dalam penelitian Sarma dan Pais (2011) menunjukkan bahwa ketimpangan pendapatan yang semakin lebar menunjukkan tingkat inklusi keuangan yang semakin rendah. Clarke et al. (2006) juga menyatakan bahwa pembangunan di sektor keuangan dapat 
mengurangi ketimpangan pendapatn. Berbeda dengan Indonesia, ketimpangan pendapatan di Indonesia yang semakin besar mengakibatkan inklusi keuangan semakin tinggi. Gambar 5 menunjukkan laju koefisien gini searah dengan inklusi keuangan di Indonesia yang setiap tahunnya mengalami peningkatan.

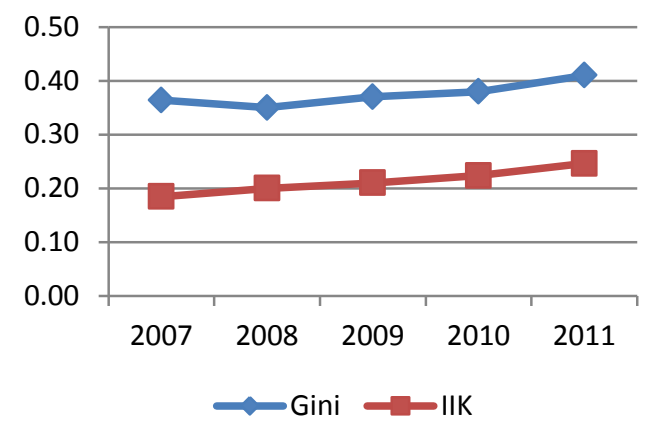

Gambar 5 Laju Koefisien Gini dan Indeks Inklusi Keuangan (IIK) di Indonesia tahun 2007-2011

Sumber : Koefisien gini (BPS 2014), IIK (hasil perhitungan peneliti)

Beberapa provinsi di Indonesia yang memiliki tingkat inklusi keuangan yang tinggi juga memiliki koefisien gini yang besar pula. Artinya, meskipun jangkauan perbankan cukup luas namun distribusi pendapatan tidak merata dengan kesenjangan yang cukup besar. Jakarta, Bali, Papua, dan Papua Barat dan beberapa provinsi lainnya merupakan provinsi yang memiliki nilai indeks inklusi keuangan dan koefisien gini di atas rata-rata. Artinya, di provinsi tersebut akses dan kegunaan jasa perbankan cukup tinggi namun kesenjangan pendapatan juga relatif besar.

Greenwood dan Jovanic (1990) menjelaskan sebuah teori terkait hubungan antara pembangunan pada sektor keuangan dengan distribusi pendapatan. Pada tahap awal pembangunan, pertumbuhan perekonomian lamban. Seiring dengan kenaikan tingkat pendapatan, sektor keuangan semakin berkembang sehingga struktur keuangan menjadi lebih luas, pertumbuhan ekonomi semakin cepat, dan ketimpangan pendapatan semakin besar. Pada tahap maturity, perekonomian memiliki struktur keuangan yang sepenuhnya telah berkembang, mencapai distribusi pendapatan yang stabil antar orang, dan memiliki tingkat pertumbuhan yang lebih tinggi dari tahap awal. Berdasarkan teori tersebut, saat ini perkembangan sektor keuangan, khususnya perbankan, di Indonesia dimungkinkan masih berada pada tahap pertumbuhan. Artinya, sektor perbankan semakin berkembang, pertumbuhan ekonomi di Indonesia semakin cepat, dan ketimpangan pendapatan antara orang kaya dengan orang miskin semakin besar.

Semakin besarnya koefisien gini, pendapatan yang semakin timpang, dapat disebabkan oleh semakin besarnya proporsi pendapatan yang diterima oleh kelompok masyarakat pendapatan tinggi, atau semakin sedikitnya proporsi pendapatan yang diterima oleh masyarakat berpendapatan rendah. Adanya hambatan terhadap akses perbankan bagi masyarakat miskin mengakibatkan perbankan sulit diakses oleh masyarakat golongan ini. Jasa perbankan hanya dapat diakses oleh masyarakat yang berpendapatan tinggi. Sehingga, berdasarkan teori Greenwood dan Jovanic (1990) dapat disimpulkan bahwa tingginya akses dan penggunaan jasa perbankan di Indonesia tidak disertai oleh perluasan fasilitas bagi masyarakat miskin. Semakin tingginya inklusi keuangan tersebut disebabkan oleh meningkatnya akses dan penggunaan jasa perbankan oleh masyarakat yang memiliki pendapatan tinggi. Namun, hal tersebut perlu dibuktikan dengan menganalisis lebih 
dalam terkait tingkat penggunaan jasa perbankan oleh masyarakat dengan tingkat pendapatan yang berbeda.

Hubungan positif antara tingkat inklusi keuangan dengan ketimpangan pendapatan juga dapat disebabkan oleh perhitungan indeks inklusi keuangan dengan metode yang kembangkan oleh Sarma belum mampu menggambarkan kondisi inklusi keuangan Indonesia yang sebenarnya. Akibatnya, hasil estimasi bertolak belakang dengan hipotesis. Oleh karena itu, pemilihan indikator dan bobot yang tepat untuk setiap dimensi merupakan faktor yang cukup penting dalam perhitungan indeks inklusi keuangan.

\section{Jumlah Pengguna Internet dan Telepon Seluler}

Perkembangan telepon seluler maupun internet menunjukkan adanya kemajuan dalam teknologi. Kedua teknologi ini dapat memperluas informasi dan mengurangi hambatan jarak dan waktu. Telepon seluler dan internet dimanfaatkan perbankan untuk memperluas akses pelayanan. Banyak perbankan yang sudah menggunakan internet dan telepon seluler sebagai media transaksi untuk mempermudah palayanan.

Jumlah pengguna internet memengaruhi positif terhadap inklusi keuangan di Indonesia pada taraf nyata 1 persen. Perbankan dapat semakin inklusif dengan meningkatkan teknologi. Fasilitas layanan melalui internet telah mempermudah nasabah dalam melakukan transaksi. Saat ini telah berkembang internet banking dimana nasabah dapat melakukan transaksi melalui jaringan internet. Teknologi internet juga dapat memperluas informasi terkait perbankan.

Jumlah pengguna telepon seluler juga memengaruhi positif terhadap inklusi keuangan di Indonesia pada taraf nyata 1 persen. Saat ini teknologi komunikasi semakin maju salah satunya adalah telepon seluler. Saat ini, telepon seluler tidak hanya digunakan untuk komunikasi saja tetapi telah dilengkapi fasilitas internet. Meskipun tidak semua pengguna telepon seluler mengakses dan menggunakan jasa perbankan, namun semakin banyaknya jumlah pengguna telepon seluler dapat meningkatkan akses perbankan. Hal ini karena perbankan pun telah mengembangkan fasilitas transaksi melalui sms banking atau mobile banking.

Berdasarkan data dari BPS, jumlah rumah tangga di Indonesia yang memiliki akses terhadap telepon seluler tahun 2007 sebesar 37\% dan meningkat menjadi 77\% pada tahun 2011. Sedangkan akses terhadap internet masih tergolong rendah, yaitu hanya sebesar 5\% pada tahun 2007 dan meningkat menjadi $24 \%$ pada tahun 2011. Seiring dengan peningkatan akses terhadap telepon seluler dan internet di Indonesia, inklusi keuangan Indonesia juga mengalami peningkatan. Hal ini karena perkembangan teknologi ini dimanfaatkan perbankan untuk menjangkau masyarakat di berbagai daerah.

Perkembangan telepon seluler juga dapat memperbaiki arus informasi dan mengurangi biaya transaksi, terutama biaya dalam menjalankan perbankan dalam bentuk fisik (Oluwatayo 2013). Adanya telepon seluler dapat meningkatkan akses perbankan bagi masyarakat yang tidak dapat terjangkau oleh perbankan terutama di negara berkembang dimana jarak dan waktu merupakan biaya yang cukup besar (Mago dan Chitokwindo 2014). Salah satu contoh sukses dari layanan perbankan melalui telepon seluler bagi masyarakat miskin adalah 
M-Pesa di Kenya. Layanan tersebut merupakan hasi dari kerjasama operator seluler dan perbankan di Kenya. Cakupan dari layanan tersebut diantaranya micro-saving dan microloan, tanpa perlu memiliki rekening perbankan.

\section{Hubungan Inklusi Keuangan dengan Pemerataan Pendapatan di Indonesia}

Analisis ekonometrika terkait hubungan inklusi keuangan dengan pemerataan pendapatan dilakukan dengan menggunakan kausalitas granger pada panel data. Inklusi keuangan diproksikan dengan indeks inklusi keuangan, sedangkan pemerataan pendapatan diproksikan dengan indeks gini. Semakin besar nilai indeks gini, distribusi pendapatan semakin tidak merata. Tahap pertama yang dilakukan dalam menganalisis hubungan kausalitas antara inklusi keuangan dan pemerataan pendapatan adalah menguji stasioneritas setiap peubah. Dari hasil pengujian menggunakan unit root test, baik indeks inklusi keuangan maupun indeks gini tidak stasioner pada level dan stasioner pada first difference.

Tabel 6 Hasil Uji Unit Root pada first difference

\begin{tabular}{lll}
\hline Peubah & $\begin{array}{l}\text { PP-Fisher } \\
\text { statistik }\end{array}$ & P-Value \\
\hline IIK & 99.65 & $0.0047^{*}$ \\
Gini & 108.56 & $0.0008^{*}$ \\
\hline
\end{tabular}

*signifikan pada taraf nyata 5\%

Setelah pengujian unit root, tahapan selanjutnya adalah pengujian panjang kointegrasi. Dari hasil uji kointegrasi Pedroni, indeks inklusi keuangan dengan indeks gini terkointegrasi pada taraf nyata 5 persen. Artinya, inklusi keuangan dengan pemerataan pendapatan memiliki hubungan jangka panjang. Sebelum melanjutkan ke tahap selanjutnya, yaitu uji kausalitas granger, dilakukan pengujian lag optimal yang akan digunakan. Dari hasil pengujian panjang lag optimum (Tabel 7), seluruh kriteria menunjukkan lap optimum di 1 . Hal ini mengindikasikan bahwa kejadian saat ini dipengaruhi oleh kejadian 1 tahun sebelumnya.

Tabel 7 Hasil Pengujian Lag Optimum

\begin{tabular}{cccccc}
\hline Lag & LR & FPE & AIC & SC & HQ \\
\hline 0 & NA & $1.94 \mathrm{e}-07$ & -9.78 & -9.71 & -9.75 \\
1 & $16.48^{*}$ & $1.68 \mathrm{e}-07^{*}$ & $-9.92^{*}$ & $-9.72^{*}$ & $-9.84^{*}$ \\
2 & 7.27 & $1.69 \mathrm{e}-07$ & -9.92 & -9.59 & -9.79 \\
\hline *panjang lag optimum pada taraf nyata \\
5\% \\
LR: sequential modified LR test statistic \\
FPE: Final prediction error \\
AIC: Akaike information criterion \\
SC: Schwarz information criterion \\
HQ: Hannan-Quinn information criterion
\end{tabular}

Setelah mendapatkan lag optimum, uji kausalitas granger dapat dilakukan. Berdasarkan analisis kausalitas granger, inklusi keuangan dengan pemerataan pendapatan memiliki hubungan satu arah (Tabel 8), yaitu pemerataan pendapatan memengaruhi tingkat inklusi keuangan di Indonesia. Tetapi, inklusi keuangan tidak mempengaruhi pemerataan pendapatan secara langsung.

Tabel 8 Hasil Pengujian Kausalitas Granger

\begin{tabular}{lcl}
\hline Null Hypothesis: & F-Statistic & Prob. \\
\hline D(GINI) does not Granger & 10.5392 & $0.0016^{*}$ \\
$\begin{array}{l}\text { Cause D(IIK) } \\
\text { D(IIK) does not Granger }\end{array}$ & 2.30740 & 0.1320 \\
\hline Cause D(GINI) & & \\
\hline *signifikan pada taraf nyata 5\%
\end{tabular}

Hubungan satu arah antara pemerataan pendapatan dengan inklusi keuangan telah dijelaskan pada subbab sebelumnya, di mana ketimpangan pendapatan yang semakin besar menyebabkan inklusi keuangan di Indonesia semakin tinggi. Tingginya akses dan penggunaan perbankan di Indonesia diakibatkan oleh tingginya 
akses dan penggunaan jasa perbankan oleh masyarakat yang memiliki pendapatan menengah ke atas. Jasa perbankan dapat dikatakan sulit diakses oleh masyarakat yang berpendapatan rendah. Banyaknya hambatan terhadap akses perbankan merupakan salah satu rendahnya akses dan penggunaan jasa perbankan. Selain dari sisi penawaran perbankan, hambatan akses juga terjadi dari sisi permintaan, misalnya pendapatan masyarakat yang sangat rendah dan kurangnya pemahaman masyarakat terkait manfaat dari jasa perbankan. Secara makro, adanya ketimpangan terhadap akses jasa perbankan dapat disebabkan oleh tidak meratanya pertumbuhan ekonomi antar provinsi di Indonesia.

\section{SIMPULAN DAN SARAN}

\section{Simpulan}

1. Hampir seluruh provinsi di Indonesia memiliki tingkat inklusi keuangan rendah. Rata-rata indeks inklusi keuangan antar provinsi di Indonesia berkisar antara 0,1-0,33, kecuali Provinsi Jakarta yang tergolong tinggi yang mencapai 0,8 . Terdapat beberapa provinsi yang awalnya diduga akan memiliki tingkat inklusi keuangan yang rendah. Setelah indeks inklusi keuangan dihitung, provinsi tersebut memiliki tingkat inklusi keuangan yang tinggi.

2. Tingkat inklusi keuangan di Indonesia dipengaruhi oleh kondisi sosial ekonomi dan infrastruktur. Faktor-faktor yang mempengaruhi positif tingkat inklusi keuangan di Indonesia adalah ukuran perekonomian, distribusi pendapatan yang digambarkan oleh koefisien gini, jumlah pengguna internet dan jumlah pengguna telepon seluler. Tingkat pengangguran dan rasio panjang jalan dimungkinkan berpengaruh jika pemberian bobot dalam perhitungan indeks inklusi keuangan tepat.

3. Inklusi keuangan memiliki hubungan searah dengan pemerataan pendapatan di Indonesia. Distribusi pendapatan di suatu daerah mempengaruhi tingkat inklusi keuangan di daerah tersebut, tetapi tidak sebaliknya.

\section{Saran}

1. Baik pemerintah maupun pelaku sektor perbankan bekerja sama untuk meningkatkan akses dan penggunaan jasa perbankan yaitu dengan meningkatkan setiap dimensi inklusi keuangan. Penetrasi perbankan dapat ditingkatkan dengan mengajak masyarakat untuk menabung. Akses perbankan dapat ditingkatkan dengan mengembangkan branchless banking seperti pengadaan ATM dan mesin setor tunai serta mobile banking. Salah satu pilar dari kebijakan Bank Indonesia terkait Strategi Nasional Inklusi Keuangan adalah fasilitas distribusi/intermediasi. Mobile banking dapat menjadi intermediasi antara penyedia jasa keuangan dengan penduduk Indonesia di berbagai daerah. Sedangkan untuk dimensi kegunaan, pemerintah, Bank Indonesia, serta stakeholder terkait dapat menyediakan kredit murah dan mudah diakses oleh pengusaha kecil yang membutuhkan modal.

2. Peningkatan pemahaman terkait jasa perbankan dengan melakukan edukasi jasa keuangan terutama bagi masyarakat yang berpendapatan rendah, perempuan, dan penduduk daerah tertinggal serta peningkatan infrastruktur fisik agar jasa keuangan dapat menjangkau masyarakat di berbagi daerah. Selain itu, pemanfaatan teknologi terutama 
telepon seluler dan internet secara efisien dapat memperluas jaringan jasa perbankan yang merata ke berbagai daerah dengan mengurangi hambatan geografis (misalnya, mobile money untuk memfasilitasi transfer dan transaksi pembayaran antar pulau, serta antar perdesaan dan perkotaan).

3. Penentuan indikator dan pemberian bobot yang tepat dari setiap dimensi inklusi keuangan adalah hal penting yang harus diperhatikan dalam perhitungan indeks inklusi keuangan di Indonesia. Penentuan indikator dari setiap dimensi inklusi keuangan disesuaikan dengan kondisi Indonesia yang memiliki kondisi sosial ekonomi beragam antar provinsi. Pemberian bobot yang berbeda dari setiap dimensi inklusi keuangan dapat menghasilkan indeks inklusi keuangan yang nilainya mendekati kondisi tingkat inklusi keuangan provinsi yang sebenarnya. Hubungan antara inklusi keuangan dengan ketimpangan pendapatan di Indonesia dapat dijelaskan dengan tepat jika indeks inklusi keuangan yang dihasilkan juga tepat.

\section{DAFTAR PUSTAKA}

Allen F, Demirguc-Kunt A, Klapper L, Peria MSM. 2012. The Foundations of Financial Inclusion: Understanding Ownership and Use of Formal Accounts. Development Research Group, Finance and Private Sector Development Team. World Bank : Working paper No 6290.

Andrianaivo M, Kpodar K. (2012). Mobile Phones, Financial Inclusion, and Growth. Review of Economics and Institution. Vol.3 No.2
Ang JB. 2010. Finance and Inequality: The Case of India. Shouthern Economic Journal. 76(3):738-761

Anggraeni L. 2009. Factor Influencing and Credit Constraints of a Financial Self-Help Group in a Remote Rural Area: The Case of ROSCA and ASCRA in Kemang Village West Java. Journal of Applied Sciences. 9(11):20672077.

[BPS] Badan Pusat Statistik 2014. Tersedia pada http://www.bps.go.id [12 Januari 2014].

[BI] Bank Indonesia. Statistik Perbankan Indonesia 2013. Tersedia pada http://www.bi.go.id/id/statistik/per bankan/indonesia/Default.aspx [9 Februari 2014].

Bank Indonesia. Statistik Perbankan Indonesia 2014. Tersedia pada Tersedia pada http://www.bi.go.id/id/statistik/per bankan/indonesia/Default.aspx [9 Februari 2014].

Bank Indonesia. 2014. Booklet Keuangan Inklusif Bank Indonesia. Tersedia pada http://www.bi.go.id/id/perbankan/ keuanganinklusif/edukasi/Content s/Buku\%20Saku\%20Keuangan\% 20Inklusif.pdf [25 September 2014].

Beck T, Demirguc-Kunt A, Levine R. 2007. Finance, Inequality and the Poor. J Econ Growth. 12:27-49.

Beck T, Demirguc-Kunt A, Peria MSM. 2006. Reaching Out: Access to and Use of Banking Services Across Country. Journal of Financial Economics. 85:234-266.

Cheng X, Degryse H. 2006. The Impact of Bank and Non-Bank Financial Institutions on Local Economic Growth in China. Tersedia pada https://feb.kuleuven.be/drc/CES/r 
esearch/dps-

papers/dps06/dps0608.pdf

Februari 2014].

Clarke GRG, Lixin Colin $\mathrm{Xu}$, Heng Fu Zou. 2006. Finance and Income Inequality: What Do the Data Tell Us?. Shoutern Economic Journal. 72(3): 578-596.

Demirguc-Kunt A, Beck T, Honohan P. 2008. Finance for All? Policies and Pitfalls in Expanding Access. Washington, DC (US): World Bank.

Demirguc-Kunt A, Klapper L. 2012. Measuring Financial Inclusion The Global Financial Index. World Bank: Working Paper No 6025.

European Commission Report. 2008. Financial Services Provision And Prevention of Financial Exclusion.

Ferreira Candida. 2014. Panel Granger Causality between Bank Efficeincy and Market Concentration in the European Union. Research in Applied Economics. 6(1):107-127

Gerdeva A, Rhyne E. 2011. Opportunities ond Obstacles to Financial Inclusion. Center of Financial Inclusion at ACCION International No.12.

Greenwood J. and Jovanovic B. (1990). Financial development, growth, and the distribution of income. $\mathrm{J}$ Pol Econ. 98(5):076-107

Hansen BE. 2004. Econometrics. Madison (US) : University of Wisconsin

Hayashi Fumio. 2000. Econometrics. New Jersey (US) : Princeton University Press

Jalilian Hossein, Kirckpatrick Colin. 2002. Financial Development and Poverty Reduction in Developing Countries. International Journal of
Finance and Economics. 7: 97108.

Konya, L. (2006). Exports and rowth: Granger Causality analysis on OECD countries with a panel data approach. Economic Modelling. 23:978-992.

Levine Ross. Juni 1997. Financial Development and Economic Growth: Views and Agenda. Journal of Economic Literature. 35(2):688-726.

Leyshon A. and Thrift N. 1995. Geographies of Financial Exclusion: Financial Abandonment in Britain and the United States. Transactions of the Institute of British Geographers. 20(3):312-341.

Mago Stephen, Chitokwindo Sibert. 2014. The Impact of Mobile Banking on Financial Inclusion in Zimbabwe: A Case of Masvingo Province. Mediterranean Journal of Social Sciences. Vol.5 No.9.

Mishkin Federic S. 2008. Ekonomi Uang, Perbankan, dan Pasar Keuangan. Lana S dan Beta YG, penerjemah; Ika PS, editor. Jakarta (ID): Penerbit Salemba Empat. Terjemahan dari: The Economic of Money, Banking, and Financial Market. Ed Ke-8.

[OJK] Ototritas Jasa Keuangan. Laporan Triwulanan OJK Tahun 2014. Tersedia pada http://www.ojk.go.id/ojkterbitkan-laporan-triwulan-itahun-2014 [12 September 2014]

Oluwatayo Isaac. 2013. Banking the unbanked in rural southwest Nigeria: Showcasing mobile phones as mobile banks among farming households. Joournal of Financial Services Marketing. 18:65-73.

Sanjaya I Made. 2014. Inklusi Keuangan dan Pertumbuhan 
Inklusif sebagai Strategi

Pengentasan Kemiskinan di

Indonesia [Tesis]. Bogor (ID):

Institut Pertanian Bogor.

Sarma Mandira. 2012. Index of

Financial Inclusion - A measure

of financial sector inclusiveness.

Berlin Working Papers on Money,

Finance, Trade and development.

Working Paper No.07/2012.

Sarma Mandira, Jesim Pais. 2011.

Financial Inclusion and

Development. J Int Dev. 23:613628.

Shahbaz M, Islam F. 2011. Financial Development and Income Inequality in Pakistan: An Application of ARDL Approach. Munich Personal RePEc Archive (MPRA). 17:13.

Tiwari AK, Shahbaz M, Islam F. 2013. Does financial development increase rural-urban income inequality? Cointegration

analysis in the case of Indian economy. Int J Soc. 40(2):151168.

Van der Werff AD, Hogarth JM, Peach ND. 2013. A Cross-Country Analysis of Financial Inclusion within the OECD. Consumer Interest Annual. Volume 59.

Wachira MI, Kihiu EN. 2012. Impact of Financial Literacy on Access to Financial Services in Kenya. International Journal of Business an Social Sience. Vol 3 No.19.

[WB] World Bank. 2009. Measuring Access to Financial Services around the World. Washington DC (US): The World Bank Group

World Bank. 2013. Global Financial Index. Tersedia pada http://data.Bank Dunia.org/datacatalog/financial_inclusion [17 Februari 2013] 